\title{
Criminal Justice and the Exclusion of Incriminating Statements in Singapore
}

\author{
Hock Lai Ho
}

\begin{abstract}
There is inevitably tension in any criminal justice system between the state's interest in securing the evidence necessary to convict a guilty party and the need to respect individual rights, uphold the rule of law and protect the legitimacy of criminal convictions. This tension is examined in the context of the criminal justice system in Singapore. A general overview is given of the criminal process, including its social and international dimensions. Focus is placed upon the law on the exclusion of incriminating statements obtained wrongfully from the accused person. The principal features of this law are the voluntariness test for the admissibility of such evidence, the oppression doctrine and the discretion to exclude incriminating statements where their prejudicial effect if admitted at the trial is likely to outweigh their probative value. In defending the operation and scope of these exclusionary rules, and the weakening of certain rights such as the right of silence and the right to counsel, local conditions and values are often invoked in official discourse. One theme that emerges is the influence of crime control ideology in shaping the criminal process.
\end{abstract}

\section{Introduction}

A tension is often said to exist in the criminal process between the interest in finding the truth and respect for the rights of persons suspected or accused of having committed a crime. The interest in the truth has two dimensions: one is the interest in finding the accused guilty when he is in fact guilty and the other is the interest in acquitting the accused when he is in fact innocent. A type 1 error occurs when a factually innocent person is convicted and a type 2 error occurs when a factually

Faculty of Law, National University of Singapore. I am grateful to my students Chan Kah Wai Kenneth, Loo Tze Ding Dorothy Ann and Ng Wei Jie Benjamin for their research assistance.

\section{H. L. Ho (凹)}

Faculty of Law, National University of Singapore (NUS), Singapore, Singapore

e-mail: lawhohl@nus.edu.sg 
guilty person is acquitted. Upholding of the rights of suspects or accused persons is sometimes motivated by the interest in protecting an innocent person from a type 1 error (that is, wrongful conviction), and this is consistent with the second aspect of the interest in determining the truth. In diluting or weakening such rights, it is the first dimension of the interest in determining the truth (avoiding a type 2 error of acquitting a factually guilty person) that is often invoked. On the standard argument, rights of individuals have sometimes to give way to the social interest in crime control. ${ }^{1}$ It is from this perspective that there is a supposed conflict between determining the truth and respect for individual rights.

This supposed conflict will be examined in relation to evidence of a confession or an incriminating statement taken from the accused person by police officers in Singapore. The principal sources of law that govern the obtaining and admissibility of such statements are the Criminal Procedure Code ('CPC'), ${ }^{2}$ the Evidence Act ('EA') ${ }^{3}$ and, to some extent, the common law. The goal of ascertaining the truth is not explicitly declared in the CPC or the EA. However, as we shall see, it underpins various aspects of the criminal process (such as the presumption of innocence, pre-trial criminal case disclosure and judicial scrutiny of the factual basis for a guilty plea), and actors in the criminal process are expected to respect the truth in discharging their respective duties. At the same time, it is recognized that the search for the truth needs to be balanced against other countervailing interests. In the 1976 case of Cheng Swee Tiang v PP, the majority of the High Court judges formulated the competing considerations thus in the context of excluding illegally obtained evidence ${ }^{4}$ :

\footnotetext{
...two important interests come into conflict when considering the question of admissibility of ... evidence [that the police had improperly] obtained. On the one hand there is the interest of the individual to be protected from illegal invasions of his liberties by the authorities and on the other hand the interest of the State to secure that evidence bearing upon the commission of crime and necessary to enable justice to be done shall not be withheld from the courts on any merely technical ground.
}

Local conditions are taken into account in deciding how the balance is to be struck. In the 2008 case of Law Society of Singapore v Tan Guat Neo Phyllis, in which issues were raised relating to the admissibility of evidence obtained in an alleged entrapment, the High Court (sitting as a bench of three judges) cautioned against uncritical following of decisions from Australia, Canada and England. It stressed that 'the legal and social environments in these jurisdictions are not the same, and that the courts in each jurisdiction must take into account the values and objectives of the criminal justice system which they wish to promote. ${ }^{5}$

\footnotetext{
${ }^{1}$ Packer, 1968 at Part II.

${ }^{2}$ Cap 68, 2012 rev. ed.

${ }^{3}$ Cap 97, 1997 rev. ed.

${ }^{4}$ Cheng Swee Tiang v. PP (1964) 30 MLJ 291 at 293.

${ }^{5}$ Law Society of Singapore v. Tan Guat Neo Phyllis [2008] 2 SLR(R) 239 at [58]. For a critique, see Ho, 2012. Similar sentiments were expressed by the High Court a year earlier in the different
} 
This chapter will proceed as follows. Part 2 provides background information. It gives an overview of the stages of the criminal process and the duties and accountability of the actors involved in the process, and discusses the main constitutional rights that exist in the context of administering criminal justice. Part 3 explores the social dimension. It discusses the extent to which the state of criminal justice has received public attention and drawn public debate. Part 4 summarizes the legal rules governing police questioning, the admissibility of statements obtained from the suspect, and the drawing of adverse inferences from omissions to mention material facts. This is followed by a study of the exclusion of incriminating statements obtained by torture in Part 5 and by other forms of undue pressure in Part 6. Part 7 addresses briefly the admissibility and effect of derivative evidence. The influence of international law on human rights is considered in Part 8 and the availability of safeguards in Part 9. Part 10 relay such little statistics as are available. Part 11 concludes with some general observations.

\section{Overview of Criminal Proceedings}

This Part provides background information by way of an overview of the administration of criminal justice in Singapore and the relevant constitutional rights.

\subsection{Stages}

\subsubsection{Investigation, Decision to Prosecute, Procedural Preliminaries}

Typically, criminal investigations begin when a first information report is filed with the police ${ }^{6}$ alleging the commission of an offence. ${ }^{7}$ The law vests the police with an array of investigative powers such as the power of arrest, entry, and search and seizure. Most pertinent for present purposes is the power to question and take statements from the suspect or accused person. This is considered in detail later.

When a person is arrested and detained in custody, the police officer must bring him before a Magistrate within 48 hours. ${ }^{8}$ The magistrate may order that he be further detained if investigation is on-going. It is not difficult to persuade the court

context of sentencing: PP v. Law Aik Meng [2007] 2 SLR(R) 814 at [19]. See also Yuan Suan Piau Steven v. PP [2013] 1 SLR 809 at [31].

${ }^{6}$ The Police Force is the main investigative agency. There are other specialised law enforcement agencies such as the Corrupt Practices Investigation Bureau and the Central Narcotics Bureau. This chapter concentrates on the Police.

${ }^{7}$ s. 14 CPC.

${ }^{8}$ s. 68 CPC; Art. 9(4) Constitution of the Republic of Singapore. 
to grant such extensions of detention. ${ }^{9}$ Upon completion of investigation, the matter will be referred to the Attorney-General's Chambers which will make an assessment of the sufficiency of admissible evidence to support a criminal conviction. ${ }^{10}$ The power to institute, conduct and discontinue criminal proceedings lies with the Attorney-General. ${ }^{11}$ Should the decision be taken to commence prosecution against the person, different court procedures will apply depending on whether the case is tried in the High Court or the State Courts.

In cases before the State Courts, the case will begin with the 'first mention' where the charge will be read and explained to him $^{12}$ after which he will be asked whether he wishes to claim trial or plead guilty to the charge. Alternatively, the court may grant an adjournment without the plea being taken. ${ }^{13}$ For more serious cases which are triable only in the High Court, the accused will first be produced before a Magistrate's Court and the charge will be explained to him. Usually this will be followed by committal proceedings where a magistrate will decide whether there are sufficient grounds for committing the accused for trial before the High Court. ${ }^{14}$ If there are not sufficient grounds, the magistrate will discharge the accused and if there are sufficient grounds, he will commit the accused for trial before the High Court. ${ }^{15}$

\subsubsection{Plea-Negotiation}

In 2004, the Attorney-General's Chambers introduced the Criminal Case Management System (CCMS). This is an arrangement that brings the prosecution and the defence together to discuss the merits of and issues in the case and to engage in plea negotiation. ${ }^{16}$ The judge is not involved in this process. If the case is

\footnotetext{
${ }^{9}$ Concerns over the ease with which extensions are obtained have been raised in Parliament. See, eg, 'Parliamentary Debates Singapore: Official Report', vol. 69 (1 June 1998) at cols. 77 (Mr J B Jeyaretnam): 'Once a person is picked up and is taken into police custody, there is, under the Constitution, a maximum limit of 48 hours that the police may hold anyone in custody before they produce them in the courts. But, unfortunately, this protection of not being kept in police custody too long is eroded by the readiness of the courts to grant such custody'.

${ }^{10}$ See generally Walter Woon, 'The public prosecutor, politics and the rule of law', The Straits Times, 29 September 2017.

${ }^{11}$ Art. 35(8), Constitution of the Republic of Singapore.

${ }^{12}$ s. 158 (a) CPC.

${ }^{13}$ s. 158(b) CPC.

${ }^{14}$ For certain types of offences, the case may be transmitted directly to the High Court for trial: $\mathrm{s}$. 175(3) and s. 210 CPC. After a recent amendment, this transmission procedure now applies to all offences: see the Addendum at the end of this chapter.

${ }^{15}$ s. 187 , CPC.

${ }^{16}$ The CCMS was launched in 2013 as part of a Code of Practice for the Conduct of Criminal Proceedings by the Prosecution and the Defence (discussed further below). See guidelines 10 and 11 of this Code which is available online at <https://www.agc.gov.sg/docs/default-source/newsroomdoucments/media-releases/2013/code-of-practice-for-the-conduct-of-criminal-proceedings-final.pdf? sfvrsn $=2>$, accessed 31 October 2018.
} 
unresolved at this stage, there is a further opportunity for resolution in the State Courts. After the trial date is set, and before the trial, the parties may agree to have the case referred for 'Criminal Case Resolution' (CCR). ${ }^{17}$ The purpose is 'to ascertain whether there are alternative options to trial that may not have been fully and adequately explored' and 'not to reduce the number of trials by actively encouraging pleas of guilty. ${ }^{, 18}$ The CCR process is facilitated by a judge who will not be the one presiding at the trial should the case remain unresolved. Plea-negotiation in Singapore at present remains largely an informal practice. ${ }^{19}$ Representations made in the course of plea-negotiation are privileged. ${ }^{20}$ 'There is a long-established practice or convention... that such representations are made "without prejudice" and that the [Public Prosecutor] will not seek to admit them in evidence against the accused should the representations be rejected., 21

\subsubsection{Pre-trial}

Prior to the trial, a criminal case disclosure conference will be held for the purpose of settling the following matters: (a) the filing of the Case for the Prosecution and the Case for the Defence; (b) any issues of fact or law which are to be tried by the trial judge at the trial proper; (c) the list of witnesses to be called by the parties to the trial; (d) the statements, documents or exhibits which are intended by the parties

\footnotetext{
${ }^{17}$ This was introduced via Subordinate Courts Registrar's Circular No. 4 of 2011. See Soh, 2011 and See, 2013.

${ }^{18}$ See See, 2013 at 78.

${ }^{19}$ See Chua Qwee Teck v. PP [1990] 2 SLR(R) 571 at [19] (“"plea bargaining”, in the sense of the court bargaining with the accused as to sentence, is not part of the administration of justice in Singapore') and at [20] ('no such thing as "plea bargaining" with the judge'). In a speech delivered at the Criminal Law Conference on 16 January 2014, the Minister of Law announced that the government was working on a formalised framework on plea bargaining: <https://www.mlaw.gov. sg/news/speeches/speech-by-min-at-criminal-law-conference-2014.html>, accessed 31 October 2018. It has since been reported that the government has decided not to implement any major changes: 'Plea Bargaining, Singapore-style', The Straits Times, 15 March 2017. According to this same report, 810 of the 851 convictions in the first two months of 2017 resulted from pleading guilty 'after some sort of talks between the prosecution and defence'. PP v. Knight Glenn Jeyasingam [1999] 1 SLR(R) 1165 at [15] where the prosecutor cited statistics revealing that only 2.3\% of persons charged in 1997 made representations (both plea and non-plea bargaining) to the AGC.

${ }^{20} P P$ v. Knight Glenn Jeyasingam [1999] 1 SLR(R) 1165. See also Azman bin Jamaluddin v. PP [2012] 1 SLR 615 at [50] and $N g$ Chye Huay v. PP [2006] 1 SLR(R) 157 (letters of representation made to the police are similarly inadmissible provided certain conditions are satisfied, namely 'the letter must refer specifically to the investigation or charge faced by the accused', it 'must have been written with the object of reducing the charge or halting investigations' and 'contain a statement that the author of the letter understands the consequence of making a false statement under s 182 of the Penal Code.' PP v. Khartik Jasudass [2015] SGHC 199 at [103]-[104].

${ }^{21}$ Law Society of Singapore v. Tan Guat Neo Phyllis [2008] 2 SLR(R) 239 at [118].
} 
to the case to be admitted at the trial; and (e) the trial date. ${ }^{22}$ The filing obligations referred to in item (a) arise from a new regime of criminal pre-trial discovery, known as 'criminal case disclosure', which came into effect in $2011^{23}$ This statutory regime of criminal case disclosure is augmented by a common law duty of disclosure. ${ }^{24}$ According to the Court of Appeal in PP $v$ Li Weiming, ${ }^{25}$ pre-trial criminal case disclosure serves the objective of finding the $\operatorname{truth}^{26}$ :

The interest of the Prosecution in a criminal trial is not to obtain a conviction at any costs, and a procedure whereby the Prosecution first lays its cards on the table is an acknowledgment that it is the duty of the Prosecution to prove its case beyond reasonable doubt and to assist the court by placing before it all relevant facts and evidence so that the truth may be ascertained... From the perspective of the accused, an early disclosure of the Prosecution's case enables him to make preparations for his defence, and although the mutual exchanges of information makes a limited incursion into the accused's right to silence, it ensures that relevant facts are not concealed from the trial judge. Reciprocal discovery, if properly implemented, therefore enhances the reliability and transparency of the criminal justice process in searching for the truth.

\subsubsection{Trial}

At the commencement of the trial, the charge will be read and explained to the accused and his plea will be taken. ${ }^{27}$ Judges are conscious of their duty to ascertain the truth even in cases where the accused elects to plead guilty. The court must be satisfied, before recording his plea, that his choice is free and informed, ${ }^{28}$ in particular, that the accused 'understands the nature and consequences of his plea' and 'intends to admit to the offence without qualification'. ${ }^{29}$ Where the accused is charged with an offence punishable with death, the High Court will not record a guilty plea unless the accused has been committed to stand trial and evidence is led by the prosecution to prove its case. ${ }^{30}$

\footnotetext{
${ }^{22}$ See ss. 160(1), 192(2), and 212(1) CPC.

${ }^{23}$ See Division 2 of Part IX and Division 2 of Part X of the CPC. This procedure applies to cases to be tried before the High Court and a significant number of cases to be tried in the District Court. Where this procedure does not apply, a pre-trial conference will be held to settle any administrative matter in relation to the trial: s. 171 CPC. For detailed discussion, see Wong, 2013.

${ }^{24}$ Muhammad bin Kadar v. PP [2011] 3 SLR 791 and Muhammad bin Kadar v. PP [2011] 3 SLR 1205. See Wong, 2013 at [14]. See also Code of Practice for the Conduct of Criminal Proceedings by the Prosecution and the Defence, above note 16, Section 4, Guidelines 40 and 41(containing non-binding guidelines on prosecutorial disclosure).

${ }^{25}$ PP v. Li Weiming [2014] 2 SLR 393.

${ }^{26}$ Ibid at [26], citing Chng, 2011 at [38].

${ }^{27}$ s. 230(1)(a) CPC.

${ }^{28}$ Yunani bin Abdul Hamid v. PP [2008] 3 SLR(R) 383 at [57].

${ }^{29}$ s. 227(2) CPC.

${ }^{30}$ s. 227(3) CPC.
} 
In practice, 'before a plea of guilty by the accused is accepted by the court, a statement of facts setting out the circumstances in which the offence is alleged to have been committed is read to the accused by the Prosecution and the accused is required to admit such statement. ${ }^{31}$ The trial judge has a legal duty to record the statement of facts and to scrutinise it to ensure that all the elements of the charge are made out on those facts. ${ }^{32}$ This is to enable the judge to ascertain that the accused understands the nature of his guilty plea and intends to admit without qualification the offence alleged against him, ${ }^{33}$ and also to assist the judge to determine the appropriate sentence. $^{34}$

Where the accused refuses to plead or does not plead or claims trial, the court will proceed to hear the case. ${ }^{35}$ Trials are of an adversarial nature. Parties are responsible for presenting their respective cases and evidence. There is no jury system; the judge acts as the fact-finder. For non-capital offences, the Law Society's Criminal Legal Aid Scheme provides legal assistance to accused persons who cannot afford to hire a lawyer and meet certain criteria. ${ }^{36}$ All persons facing capital charges are eligible for free legal representation under the Legal Assistance Scheme for Capital Offences which is administered by the Supreme Court. ${ }^{37}$

At the commencement of the trial, the prosecutor will present an opening address in which he will state shortly the nature of the offence and the evidence he proposes to adduce. ${ }^{38}$ Following the opening address, the prosecutor will proceed to present the evidence. After the prosecutor has examined a witness, the defence will have the opportunity to cross-examine him, and this may be followed by re-examination of the witness by the prosecutor. ${ }^{39}$ After the prosecutor has concluded its case, it is open to the defence to apply to dismiss the case on the ground that there is no case to answer. ${ }^{40}$ The court will then have to decide whether the prosecution has succeeded in producing 'some evidence which is not inherently incredible and which

\footnotetext{
${ }^{31}$ Chota bin Abdul Razak v. PP [1991] 1 SLR(R) 501 at [11]. See also Mok Swee Kok v. PP [1994] $3 \mathrm{SLR}(\mathrm{R})$ 134. A statement of agreed facts could also be tendered as a formal admission of guilt by the accused: PP v. Mohamad Noor bin Abdullah [2017] 3 SLR 478.

${ }^{32}$ Mok Swee Kok v. PP [1994] 3 SLR(R) 134 at [14].

${ }^{33}$ Chota bin Abdul Razak v. PP [1991] 1 SLR(R) 501 at [16].

${ }^{34}$ Mok Swee Kok v. PP [1994] 3 SLR(R) 134 at [14]; Biplob Hossain Younus Akan v. PP [2011] 3 SLR 217 at [9].
}

${ }^{35}$ s. $230(1)(\mathrm{c}) \mathrm{CPC}$.

${ }^{36}$ This scheme, which began in 1985 , has been enhanced with direct government funding since January 2015. See Thio, 2015. It is reported that 2433 persons were helped under the enhanced scheme in 2015, a five-fold increase from the number in 2014: 'Criminal Legal Aid Scheme helping more accused people', The Straits Times, 29 February 2016.

${ }^{37}$ Information is available from the website of the Supreme Court. See $<$ http://www.supremecourt. gov.sg/rules/court-processes/criminal-proceedings/legal-assistance-scheme-for-capital-offences(lasco)>, accessed 31 October 2018.

\footnotetext{
${ }^{38}$ s. $230(1)(d)$ CPC.

${ }^{39}$ s. $230(1)(\mathrm{e}) \mathrm{CPC}$.

${ }^{40}$ s. $230(1)(f)$ CPC.
} 
satisfies each and every element of the charge ${ }^{41}$; if the court forms the view that such evidence exists, it will call on the accused to give his defence. ${ }^{42}$ At this point, the court will have to inform the accused of the following options ${ }^{43}$ :

First, if you elect to give evidence you must give it from the witness box, on oath or affirmation, and be liable to cross-examination. Second, if you elect not to give evidence in the witness box, that is to say, remain silent, then I must tell you that the court in deciding whether you are guilty or not, may draw such inferences as appear proper from your refusal to give evidence, including inferences that may be adverse to you.

When the court calls upon the accused to give his defence, he may either plead guilty or choose to enter his defence. ${ }^{44}$ Should the latter option be taken, the defence will proceed to open its case and call its witnesses. ${ }^{45}$ The accused cannot be compelled to give evidence. ${ }^{46}$ However, if he chooses not to give evidence at his trial, the court may draw adverse inferences against him as appear proper. ${ }^{47}$ If the accused elects to take the witness stand, his evidence must be given on oath or affirmation and he is liable to cross-examination. After the defence has presented its evidence, it will give a closing address to which the prosecution will have the final right of reply. ${ }^{48}$

Thereafter the court will deliberate and give its judgment. If the court finds the accused guilty as charged, it will proceed to hear submissions by the prosecution and the plea in mitigation by the defence prior to deciding on the sentence. ${ }^{49}$

\subsubsection{Post-trial}

The prosecution may appeal against the acquittal of the accused and the sentence delivered by the trial court. Similarly, the accused may appeal against his conviction and against his sentence. ${ }^{50}$ There is also the possibility of petitioning to the High Court for criminal revision in respect of criminal proceedings and matters in the State Courts. ${ }^{51}$ This power is 'exercised sparingly' and 'the possible existence

\footnotetext{
${ }^{41}$ This is a low evidential threshold. At this stage, the court is not to decide whether the prosecution has proved its case beyond reasonable doubt.

${ }^{42}$ s. $230(1)(j)$ CPC.

${ }^{43}$ s. 230(1)(m) CPC.

${ }^{44}$ s. 230(1)(n) CPC.

${ }^{45}$ s. $230(1)(o),(p)$ CPC.

${ }^{46}$ s. 122(3) EA; s. 291(4) CPC.

${ }^{47}$ s. 291(3) CPC.

${ }^{48}$ s. $230(1)(u),(v)$ CPC.

${ }^{49}$ s. 228 CPC.

${ }^{50}$ See ss. 374(3) and (4) CPC respectively. See generally, Part XX of the CPC for the appeal procedure.

${ }^{51}$ s. 23 Supreme Court of Judicature Act, Cap 322, 2007 rev. ed.
} 
of a serious injustice must be present' before the High Court will act. ${ }^{52}$ The option of petitioning for criminal revision is important to an accused person whose conviction was on a guilty plea. This is because once a guilty plea is entered, the accused loses the right to appeal on the conviction. ${ }^{53}$ 'In such a situation, an application by way of criminal revision would be the only means by which the accused could have a wrongful conviction set aside. ${ }^{54}$ An appropriate situation for the exercise of this revisionary power is where 'additional evidence before the reviewing court casts serious doubts as to the guilt of the accused' 55

\subsection{Actors: Duties and Accountability}

\subsubsection{Police Officers}

An important function of the police is crime detection. The law confers on the police an array of powers to perform this function. Most pertinent for our purposes is the power to detain and question suspects. ${ }^{56}$ The Police Force Act (PFA) ${ }^{57}$ contains provisions on 'duties and discipline of police officers'. ${ }^{58}$ Under section 28 PFA, senior police officers may be disciplined under the authority of the Public Service Commission. Disciplinary proceedings against senior police officers are regulated by the Public Service (Disciplinary Proceedings) Regulations. For officers below the rank of inspector, disciplinary proceedings are provided for in the Police Regulations. The Internal Affairs Office is an investigation entity within the Singapore Police Force which is tasked to conduct investigations into disciplinary offences and crimes committed by police officers. ${ }^{59}$ Police improprieties in the course of conducting investigation, including interrogation of suspects, are referred to the Internal Affairs Office for investigation. Such improprieties may constitute a disciplinary offence under section 40 of the Police Force Act as well as a criminal offence. ${ }^{60}$

\footnotetext{
${ }^{52}$ Yunani bin Abdul Hamid v. PP [2008] 3 SLR(R) 383 at [56].

${ }^{53}$ s. 375(1) CPC. The accused may appeal only against the extent or legality of the sentence.

${ }^{54}$ Yunani bin Abdul Hamid v. PP [2008] 3 SLR(R) 383 at [43].

${ }^{55}$ Yunani bin Abdul Hamid v. PP [2008] 3 SLR(R) 383 at [56].

${ }^{56}$ See Part IV of the CPC.

${ }^{57}$ Cap 235, 2006 rev. ed.

${ }^{58}$ See Part III Division 1 and Division 2 of the PFA. Sections 117-119 of the PFA empowers the Commissioner to make Police Regulations, General, Force and Standing Orders.

59'Parliamentary Debates Singapore: Official Report', vol. 63 (25 August 1994) at cols. 381-2 (calls to make the Internal Investigation Section (now Internal Affairs Office) independent of the police force were rejected).

${ }^{60}$ The officer may be prosecuted for an offence under the Penal Code, Cap 224, 2008 rev. ed., or under other legislation such as the Prevent of Corruption Act, Cap 241, 1993 rev. ed. (see, eg, PP v. Peter Benedict Lim Sin Pang [2013] SGDC 192). Voluntarily causing hurt or grievous hurt to extort a confession is criminalised under s. 330 and s. 331 of the Penal Code respectively; $c f . P P$ v. $G B Z$ [2017] SGDC 271 (involving a private citizen causing hurt to another in order obtain a confession).
} 
While criminal prosecution ${ }^{61}$ of, and civil claims against, ${ }^{62}$ police officers do occur, more often than not the matter is dealt with as a disciplinary offence. ${ }^{63}$

\subsubsection{Prosecutors}

Under the Legal Profession (Professional Conduct) Rules $2015,{ }^{64}$ the prosecutor 'must present the evidence against an accused person fairly and impartially, and without malice, fear or favour' ${ }^{65}$ and 'must comply with the constitutional, evidential and procedural rules which operate in a criminal trial'. ${ }^{66}$ As a general principle, the prosecutor 'is under a fundamental duty to assist in the administration of justice ${ }^{67}$ and 'must assist the court... by drawing the court's attention to any apparent error..., any apparent omission of fact, and any procedural irregularity, which...ought to be corrected.' ${ }^{68}$ The Supreme Court has jurisdiction to discipline public prosecutors for professional misconduct under section $82 \mathrm{~A}$ of the Legal Profession Act. ${ }^{69}$ In a speech by a judge of the Supreme Court, who was

\footnotetext{
${ }^{61}$ See, eg, 'Cop beat up suspect at police post', The Straits Times, 5 July 2002; Chua Yong Khiang Melvin v. PP [1999] 2 SLR(R) 1108; Mohd Shahrin bin Shwi v. PP [1996] 3 SLR(R) 174; Vance John Doray v. PP [2001] SGMC 43.

${ }^{62}$ In Zainal bin Kuning v. Chan Sin Mian Michael [1996] 2 SLR(R) 858, the plaintiffs brought a civil action against a police inspector for false imprisonment and malicious prosecution, alleging that false incriminating statements had been obtained from them by subjecting them to assault and other forms of ill treatment: ibid at [18]-[20]. The Court of Appeal upheld the decision of the trial court to dismiss the plaintiffs' action with costs. It seems that this was one of the cases that prompted a member of Parliament to propose the setting up of a commission of inquiry to look into the state of criminal justice in Singapore: see 'Parliamentary Debates Singapore: Official Report', vol. 69 (1 June 1998) at cols. 75-108, especially col. 92.

${ }^{63}$ See s. 40 PFA. The disciplinary offences set out in the Schedule to this Act include 'conduct to the prejudice of good order and discipline' (item 3 ) and 'excess of duty resulting in loss or injury to any other person' (item 12). See, eg, Leong Kum Fatt v. AG [1985-1986] SLR(R) 165: a police inspector was dismissed after a disciplinary hearing for assaulting two suspects and failed in his application for judicial review of the disciplinary decision.

${ }^{64}$ S.706/2015.

${ }^{65}$ Rule $15(2)$.

${ }^{66}$ Rule 15(1)(b).

${ }^{67}$ Rule 15(1)(a).

${ }^{68}$ Rule 15(6).

${ }^{69}$ Cap 161, 2009 rev. ed. See Re Nalpon Zero Geraldo Mario [2012] 3 SLR 440 (High Court), unsuccessful application made by defence counsel under this section. Subsequently the Attorney-General filed a complaint against the defence counsel to the Law Society for, among other things, making and disseminating to various third parties offensive remarks, including remarks that would undermine the integrity of the office of the Attorney-General. The defence counsel was eventually censured by the Court. See Law Gazette, June 2014, 'Findings and Determination of the Disciplinary Tribunal, In the matter of Zero Geraldo Mario Nalpon, an Advocate and Solicitor', available online at <http://v1.lawgazette.com.sg/2014-06/>, accessed 31 October 2018.
} 
formerly the Attorney-General, the following was said of the ethical duties of prosecutors $^{70}$ :

The goal of the prosecution is not to secure a conviction at all costs.... ${ }^{71}$ Because the decision to charge an accused is made after a process of careful consideration, the Prosecutor would be expected to pursue the case with vigour to secure the conviction of one whom he sincerely believes to be guilty. Yet, the point is that the desire to secure a conviction flows from his basic commitment to justice: the Prosecutor desires to convict the guilty only because that is what justice demands. The fact that the Prosecutor's ultimate duty is to justice also means that the Prosecutor has a duty to withdraw a charge or, even, to apply for a criminal revision if clear evidence emerges to disprove the guilt of the accused.

The same emphasis on fairness was stressed recently in a speech delivered by the Attorney-General at the Opening of Legal Year 2016 where he stated ${ }^{72}$ :

There is no point in securing convictions if the public is not confident that the process is fair and the convictions are safe... [P]rosecutors have a special responsibility to uphold the integrity of the criminal justice system. We share a responsibility with the court for ensuring that prosecution is carried out fairly and the process is one in which the public can have confidence. Fulfilling this responsibility is a big part of a prosecutor's role.

\subsubsection{Defence Counsel}

Defence counsel is 'under a fundamental duty to assist in the administration of justice. ${ }^{73} \mathrm{He}$ 'must pursue every reasonable defence, and raise every favourable factor, on behalf of the accused person in accordance with the law, ${ }^{74}$ and must not be influenced by his 'personal opinion as to whether the accused person is guilty ${ }^{75}$ Where the accused person confesses to the defence counsel, the latter may continue to represent him but 'must not adduce any evidence or make any submission which is inconsistent with the confession' ${ }^{76}$ As the judge in the same speech noted above puts it, 'the goal of criminal defence is not to secure an acquittal at all costs.' 'The duty of the Defence Counsel is to ensure that no conviction is entered unless it is

\footnotetext{
${ }^{70}$ Chong, 2015 at [9].

${ }^{71}$ See Muhammad bin Kadar and another v. PP [2011] 3 SLR 1205 at [200]: 'the duty of the Prosecution is not to secure a conviction at all costs. Rather, the Prosecution owes a duty to the court and to the wider public to ensure that only the guilty are convicted, and that all relevant material is placed before the court to assist it in its determination of the truth.'

${ }^{72}$ Speech delivered by the Attorney-General, Mr V K Rajah, SC, at the Opening of the Legal Year 2016 on 11 January 2016, at [14], available online at <https://www.agc.gov.sg/docs/defaultsource/speeches/2016/ag's-oly-speech-2016-(as-delivered)-(4).pdf?sfvrsn=2>, accessed on 31 October 2018.

${ }^{73}$ Rule 14(1), Principle (a) of the Legal Profession (Professional Conduct) Rules 2015.

${ }^{74}$ Ibid, rule $14(2)$.

${ }^{75}$ Ibid, rule $14(3)(\mathrm{b})$.

${ }^{76}$ Ibid, rule $14(4)$.
} 
done: (a) by a competent Court; and (b) upon legal evidence sufficient to support a conviction. ${ }^{77}$

In May 2013, a Code of Practice for the Conduct of Criminal Proceedings was jointly issued by the Attorney-General's Chambers and the Law Society of Singapore. ${ }^{78}$ This Code does not have the force of law. ${ }^{79}$ It merely sets out best practices guidelines in the conduct of criminal proceedings' by the Prosecution and the Defence. ${ }^{80}$ The guidelines are aspirational and non-binding. One of them stresses that both prosecutors and defence counsel must 'respect the fundamental rights of suspects and the right of the accused person to a fair trial' ${ }^{81}$

\subsubsection{Judges}

The trial judge's role is to make findings of fact on the basis of admissible evidence that the parties have adduced before the court. ${ }^{82}$ In XP $v P P,{ }^{83}$ the Singapore High Court viewed the presumption of innocence and the prosecution's burden to prove guilt beyond reasonable doubt as a reflection of the judicial duty to search for the truth. The trial judge has a duty to assess the evidence with care. He is required 'to apply his mind to the evidence; to carefully sift and reason through the evidence to ensure and affirm that his finding of guilt or innocence is grounded entirely in logic and fact. ${ }^{, 84}$ In Thong Ah Fat $v P P,{ }^{85}$ the Court of Appeal held that there was an inherent duty at common law for judges to give reasons for their decisions, including decisions on matters of fact. ${ }^{86}$

Given the adversarial nature of the trial, the presentation of evidence is generally controlled by the parties. However, this is qualified by section 167(1) EA. This provision gives the trial judge wide powers to intervene in the proceedings by directly asking questions of witnesses and parties and to order the production of any evidence. However, the courts have exercised self-restraint in using this power. ${ }^{87}$ In an adversarial system, the trial judge is to take a relatively passive role and must not 'descend into the arena'. ${ }^{8}$

\footnotetext{
${ }^{77}$ Chong, 2015 at [11].

${ }^{78}$ See above note 16.

${ }^{79} \mathrm{Ibid}$, guideline 2 .

${ }^{80} \mathrm{Ibid}$, guideline 1 .

${ }^{81}$ Ibid, guideline $7(\mathrm{~d})$.

${ }^{82}$ See s. 167(2) EA which states: 'The judgment must be based upon facts declared by this Act to be relevant and duly proved.'

${ }^{83} X P$ v. $P P$ [2008] 4 SLR(R) 686 at [98].

${ }^{84}$ Jagatheesan s/o Krishnasamy v. PP [2006] 4 SLR(R) 45 at [61].

${ }^{85}$ Thong Ah Fat v. PP [2012] 1 SLR 676.

${ }^{86}$ See also Lai Wee Lian v. Singapore Bus Service (1978) Ltd. [1983-1984] SLR(R) 388.

${ }^{87}$ See, eg, Yap Chwee Khim v. American Home Assurance Co [2001] 1 SLR(R) 638 at [25].

${ }^{88}$ Mohammed Ali bin Johari v. PP [2008] 4 SLR(R) 1058 at [154].
} 
Judicial findings of fact at the trial level is subject to appellate control. Although appellate courts are conscious that the trial judge is generally better placed to assess evidence, especially oral evidence of witnesses, they will intervene in appropriate circumstances. $^{89}$

\subsection{Constitutional Rights in the Criminal Process}

Article 9 of the Singapore Constitution provides for a limited number of rights in relation to the administration of criminal justice. They are the right not to be deprived of life or personal liberty 'save in accordance with law', the right to counsel, and the right to be brought before the magistrate within 48 hours of his arrest.

\subsubsection{Right to Counsel}

The right to be defended by a lawyer at the trial is also to be found in section 236 CPC. ${ }^{90}$ However, the present discussion is on the right to counsel prior to the trial while the person is being investigated and in police custody. While Article 9(3) of the Constitution provides that ' $[\mathrm{w}]$ here a person is arrested, he ... shall be allowed to consult... a legal practitioner of his choice', this right has failed to receive as strong a vindication as in other jurisdictions. First, it has been held that the police do not have to inform the arrestee of his right to counsel. The judiciary has declined to read this 'further right' into article $9(3) .{ }^{91}$ Neither has the arrested person any right to contact family members or friends. ${ }^{92}$ Secondly, the Courts have held that article 9(3) does not require the police to give the accused access to legal advice immediately upon arrest. The police do not have to wait for him to receive legal advice before they start to question and take statements from him, and the lawyer is not and does not need to be present during the questioning. ${ }^{93}$ It is not uncommon to deny access to counsel until the investigation is completed and the police have

\footnotetext{
${ }^{89}$ See, eg, PP v. Muhammad Farid bin Mohd Yusop [2015] 3 SLR 15 at [54].

${ }^{90}$ It states: 'Every accused person before any court may of right be defended by an advocate.'

${ }^{91}$ Rajeevan Edakalavan v. PP [1998] 1 SLR(R) 10 at [19]-[21]; Sun Hongyu v. PP [2005] 2 SLR (R) 750 at [34].

${ }^{92}$ Sun Hongyu v. PP [2005] 2 SLR(R) 750; criticized by Thio, 2012 at [12.088], [12.089].

${ }^{93}$ See Muhammad bin Kadar v. PP [2011] 3 SLR 1205 at [57]: 'Even after the accused engages counsel (assuming he does), there is no legal rule requiring the police to let counsel be present during subsequent interviews with the accused while investigations are being carried out.' But the situation appears to be different after the investigation has been completed. In Azman bin Mohamed Sanwan v. PP [2012] 2 SLR 733 (CA), the investigating officer visited the accused at the Queenstown Remand Prison after investigation had apparently been completed and he took further statements from the accused. These visits were made without informing, and in the absence of, counsel appointed by the accused. The Court of Appeal and the Deputy Public Prosecutor himself were of the view that the conduct of the investigating officer was improper.
} 
taken all the statements that they want from the suspect. ${ }^{94}$ As judicially construed, article 9(3) is satisfied so long as the person is allowed to consult a lawyer 'within a reasonable time after his arrest'. ${ }^{95}$ In James Raj s/o Arokiasamy v PP, ${ }^{96}$ the Court of Appeal highlighted the need to balance 'the arrested person's undoubted right to legal representation' and 'the public interest in enabling the police to discharge their duty and carry out investigations effectively and expeditiously'. ${ }^{97}$ The inability to get early access to their clients has long been a major source of concern for the criminal bar. $^{98}$

\subsubsection{Right not to Deprived of Life or Personal Liberty Save in Accordance with Law}

Article 9(1) is the closest provision that one can find in the Constitution relating to the right to a fair trial. It states that no one shall be deprived of life or personal liberty save in accordance with 'law'. In Ong Ah Chuan v PP, ${ }^{99}$ the constitutionality of a statutory provision which created a rebuttable legal presumption was challenged. This case is not immediately related to the present project but it is noteworthy for interpreting 'law' for the purposes of article 9(1) as including fundamental rules of natural justice. In Yong Vui Kong v AG, ${ }^{100}$ the Court of Appeal interpreted Ong Ah Chuan as endorsing the view that:

... [the Singapore] criminal justice system contains the following fundamental elements: (a) the accused can be convicted of the offence charged only if the ingredients of the offence have been proved by the Prosecution according to the standard of proof applicable to criminal proceedings (i.e., the standard of beyond reasonable doubt); (b) the tribunal trying

\footnotetext{
94، 'Lawyers can seek earlier access to accused persons', The Straits Times, 27 April 2007 (pilot scheme which allows lawyers to request to see their clients towards the end of their remand period provided it does not interfere with investigations).

${ }^{95}$ Lee Mau Seng v. Minister for Home Affairs [1971-1973] SLR(R) 135 at [12]; Jasbir Singh v. PP [1994] 1 SLR(R) 782; James Raj s/o Arokiasamy v. PP [2014] 3 SLR 750.

${ }^{96}$ James Raj s/o Arokiasamy v. PP [2014] 3 SLR 750 at [31].

${ }^{97}$ See also 'Parliamentary Debates Singapore: Official Report', vol. 69 (1 June 1998) at col. 99 (Minister of State for Home Affairs, Assoc Prof Ho Peng Kee): 'In Singapore, we see it right to balance the rights of an accused to be given a fair trial with the right of the State to devise rules to ensure that those who are guilty will not take advantage of the law and get away scot-free. Hence, under our approach, a suspect has no inherent right to have his lawyer present when the Police questions him.'

${ }^{98}$ This concern has been aired many times and most recently in the speech of the President of the Law Society delivered at the Opening of the Legal Year 2016 on 11 January 2016, at [14]-[15]. Available online at $<$ https://www.lawsociety.org.sg/Portals/0/MediaAndResourceCentre/Speeches/ President's\%20OLY\%202016\%20speech\%20(as\%20of\%201\%20Jan\%2016\%203\%2011pm).pdf>, accessed 31 October 2018. This speech received media attention: see 'LawSoc repeats call for accused to have early access to lawyers', Today, 12 January 2016.

${ }^{99}$ Ong Ah Chuan v. PP [1979-1980] SLR(R) 710.

${ }^{100}$ Yong Vui Kong v. AG [2011] 2 SLR 1189 at [107].
} 
the accused must be independent and unbiased; and (c) the accused must be heard on his defence to the offence charged. Accordingly, legislation that abrogates any of these fundamental elements may be open to challenge on the ground of inconsistency with Art 9(1).

The Court of Appeal has held that the right of silence, discussed below, is not a fundamental rule of natural justice protected under Article 9(1). ${ }^{101}$ This Article was relied upon unsuccessfully in a number of cases to challenge the constitutionality of the statutory power to draw an adverse inference from the accused's silence or omission to mention material facts in his statement to the police. ${ }^{102}$

\section{Social Interest in Criminal Justice}

\subsection{Media Publicity and Public Comments}

Criminal trials are held in open court. They are not televised. ${ }^{103}$ In 1987, a number of persons were arrested and detained without trial under the Internal Security Act over an alleged Marxist plot to overthrow the government. Confessions by these persons were aired publicly on television. Allegations that these persons were tortured into confessing were rejected by the Government. ${ }^{104}$

Criminal cases regularly receive press and other media coverage. This is allowed by the law but is subject to the doctrine of sub judice contempt. Under that doctrine, publication of views that carry a real risk of prejudice to or interference with pending court proceedings amounts to criminal contempt of court. ${ }^{105}$ In 2013, a blogger put on the internet videos of interviews with two persons who claimed that police officers had assaulted them to get confessions. The videos were published while criminal proceedings were pending against those two persons. This led to a letter being issued by the Attorney-General's Chambers to the blogger warning her that she has committed contempt of court. It was deemed that a letter of warning was sufficient and no committal proceedings for contempt were instituted against her. ${ }^{106}$

Under guidelines contained in the Code of Practice for the Conduct of Criminal Proceedings by the Prosecution and the Defence, prosecutors and defence 'should avoid making public comments outside the courtroom including, inter alia, speaking to the media about the merits of particular cases or the details of the guilt

\footnotetext{
${ }^{101} P P$ v. Mazlan bin Maidun [1992] 3 SLR(R) 968.

${ }^{102}$ Jaykumal v. PP [1981-1982] SLR(R) 147; Haw Tua Tau v. PP [1981-1982] SLR(R) 13.

${ }^{103}$ An unauthorised recording of court proceedings amounts to an act of contempt of court under $\mathrm{s}$. 5 of the Administration of Justice (Protection) Act 2016.

${ }^{104}$ See 'Parliamentary Debates Singapore: Official Report', vol. 49 (29 July 1987), especially at cols. 1441-1443, 1465-1466, 1474, 1491-1492, 1508.

${ }^{105}$ This common law offence was codified in 2016. It is now governed by s. 3(1)(b) of the Administration of Justice (Protection) Act 2016.

${ }^{106}$ See 'Film-maker warned over bus driver videos', The Straits Times, 15 June 2013; 'Contempt of court: AGC can decide over prosecution', The Straits Times, 24 June 2013.
} 
or innocence of the accused person before judgment by the court, and making any public statements regarding the character, credibility, reputation, or record of an accused person. ${ }^{, 107}$ Further, they 'should not give any statement to the press or media that may amount to contempt of court or that is calculated to interfere with the fair trial of a case that has not been concluded. ${ }^{108}$

\subsection{Public Interest in Miscarriages of Justice}

Occasionally, allegations of police abuse of suspects are reported in the press ${ }^{109}$ and online fora, ${ }^{110}$ and raised in Parliament. In all instances, the allegations were rejected by the government.

Noteworthy instances include one that occurred in 1994. The accused, a Thai construction worker, was prosecuted for murder. He alleged a series of ill-treatment at the hands of the investigating officers that included punching, kicking, hair-pulling, and hitting the sole of his feet with a cane. There was also evidence of a broken needle lodged in the accused's arm. The defence claimed that this resulted from the accused having been pricked with a sharp object when he used his arm to block an officer whom he thought was going for his eyes with the object. However, the accused's allegations were denied by the officers. After considering all the evidence, the trial judge excluded the statements because it 'appeared to [him] that the accused had been assaulted'. ${ }^{111}$ The accused was acquitted and discharged without calling for his defence. This case drew public attention and the matter was raised and discussed in Parliament. ${ }^{112}$ A year later, the accused was prosecuted and convicted for making up false evidence that the police were responsible for the needle in his arm. ${ }^{113}$ It seems from the evidence adduced at the later trial that the accused had three other needles in his limbs. The needles, including the one that was

\footnotetext{
${ }^{107}$ Above note 16 , guideline 52 .

${ }^{108} \mathrm{Ibid}$, guideline 53 .

${ }^{109} \mathrm{See}$, eg, 'Alleged Rioters file complaint claiming abuse by police; investigations into the veracity of the allegations are ongoing: Police spokesperson', Today, 9 January 2014. Alleged practices of mistreatment of persons detained for questioning by the Corrupt Practices Investigation Bureau were reported in 'Ways to make you talk...', The Straits Times, 8 April 2007 and 'Interrogation techniques designed to inflict mental and physical torture and break the toughest minds', The Straits Times, 22 April 2007.

${ }^{110}$ See, eg., 'SPF Internal Affairs Office initiated investigation on allegation of police violence', available online at $<\mathrm{http} / / / \mathrm{www}$.theonlinecitizen.com/2014/01/spf-internal-affairs-office-initiatedinvestigation-on-allegation-of-police-violence/>, accessed 31 October 2018.

${ }^{111}$ PP v. Somporn Chinphakdee [1994] SGHC 209. An appeal by the prosecution against the acquittal was dismissed by the Court of Appeal. See 'Thai worker jailed five years for making up false evidence', The Straits Times, 3 February 1995.

112، Parliamentary Debates Singapore: Official Report', vol. 63 (25 August 1994) at col. 377-385; 'No black sheep allowed to tarnish integrity of ministry', The Straits Times, 26 August 1995.

${ }^{113}$ 'Thai worker jailed five years for making up false evidence', The Straits Times, 3 February 1995.
} 
revealed at the first trial, were believed be 'charm needles' inserted long ago for superstitious purposes.

There have been a few well-publicized cases in which an accused person had his conviction subsequently overturned by the appellate court or had charges against him withdrawn. For example, in 1993, a murder charge was withdrawn against the accused after evidence emerged which indicated that he was out of the country at the time of the crime. The accused had been charged on the basis of a confession obtained by officers of the Criminal Investigation Department ('CID'). Questions were raised in Parliament ${ }^{114}$ and in the press ${ }^{115}$ about possible impropriety in the manner in which the confession was obtained. The Minister for Home Affairs said in Parliament that he was 'completely satisfied' that there was no impropriety. ${ }^{116}$ When asked why he had confessed, the accused told the press: 'I was scared. It's easy for people to ask why but I am the one who suffered in the CID.' He declined to elaborate on how he suffered except to say: 'You never know what you are going to face in the CID.' 117

A more recent example occurred in 2011. Mr. Ismil Kadar had his conviction for murder overturned by the Court of Appeal. By then he had already spent six years in prison. ${ }^{118}$ In acquitting the accused, the Court of Appeal criticised the investigating officer for serious procedural lapses in the way he had taken statements from the accused and the prosecution for failing to make early disclosure of evidence to the defence. ${ }^{119}$

\section{Incriminating Statements by the Accused: Relevant Rules of Evidence and Procedure}

The prosecution does not have to produce any confession by the accused in order to secure a conviction. However, in most cases, the police are able to obtain a confession or other incriminating statements from the accused. It is very common for the prosecution to rely on evidence of such statements at a trial. ${ }^{120}$ Confessions tend

\footnotetext{
114،Parliamentary Debates Singapore: Official Report', vol. 61 (12 April 1993) at cols. 14-15.

${ }^{115}$ See, eg, 'Some questions about Samat's case', The Straits Times, 24 March 1993; 'Prosecutor notified of alibi 23 months after Samat's arrest', The Straits Times, 30 March 1993. The acquittal received considerable press coverage. See, $e g$, 'Court frees innocent man after $2 \frac{1}{2} 2$ years' jail', The Straits Times, 18 March 1993 and 'Confession based on crimewatch', The Straits Times, 18 March 1993.

${ }^{116}$ 'Parliamentary Debates Singapore: Official Report', vol. 61 (12 April 1993) at cols. 14-15.

${ }^{117}$ 'Confession based on crimewatch', The Straits Times, 18 March 1993.

${ }^{118}$ 'Man accused of murder freed after 6 years in jail', The Straits Times, 6 July 2011.

${ }^{119}$ Muhammad bin Kadar v. PP [2011] 3 SLR 1205.

${ }^{120} \mathrm{~A}$ distinction is drawn in s. 17 EA between a confession and a less incriminating statement known as an admission. But the courts have construed the meaning of 'confession' very broadly to include any statement that connects the accused in some way with the offence. See, eg, Tong Chee Kong v. PP [1998] 1 SLR(R) 591 at [18].
} 
to be given a lot of weight. In the Court of Appeal case of Lee Chez Kee $v P P,{ }^{121} \mathrm{~V}$. K. Rajah JA attributed this to the fact that 'a confession is inculpatory in nature'; 'it is a statement made against the interest of its maker and hence inherently more reliable.' A person may be convicted on the basis of his pre-trial confession alone even if he retracts it at the trial, and no corroboration is required. ${ }^{122}$ It is also possible to convict a person based solely on the confession of a co-accused provided 'that the evidence emanating from that confession satisfies the court beyond reasonable doubt of the accused's guilt., 123

It is because confession evidence is believed to be so highly probative of guilt that there is a reluctance to exclude it. This comes from the desire not to let the guilty go free. At the same time, it is also because the evidence can play such a decisive role in securing a conviction that its admissibility should be conditional on there being sufficient assurance of reliability and on its lawful and fair provenance. This springs from our interest in the accuracy and legitimacy of the conviction.

\subsection{Rules on the Obtaining of Evidence}

The police are legally constrained in seeking evidence. Certain methods of obtaining evidence are criminal or otherwise wrongful. For example, it is both a crime and a tort (a civil wrong) to extract a confession from a suspect by physically assaulting him. ${ }^{124}$ The law that make this conduct criminal or tortious are general in the sense that it is not aimed specifically at regulating the process of obtaining evidence for a criminal prosecution. Some rules do have that specific aim. For example, the CPC requires the police to obtain a search warrant before they may conduct a search of premises for incriminating evidence and the court will grant the warrant only if certain conditions are satisfied. ${ }^{125}$ Another example, one on which this chapter focuses, is the set of rules that regulate the obtaining of statements from the accused.

The police have the power under section $21 \mathrm{CPC}$ to order anyone 'who appears to be acquainted with any of the facts and circumstances of the case' to attend before them. This includes the suspect. Section 22(1) empowers the police to question this person. ${ }^{126}$ When questioned, the person must state truly what he

\footnotetext{
${ }^{121}$ Lee Chez Kee v. PP [2008] 3 SLR(R) 447 at [102].

${ }^{122}$ See, eg, Ismail bin U K Abdul Rahman v. PP [1974-1976] SLR(R) 91 at [84].

${ }^{123}$ Chin Seow Noi v. PP [1993] 3 SLR(R) 566, interpreting a former provision that now exists as s. 358(5) CPC. The soundness of this interpretation was questioned, in passing, by V K Rajah JA in Lee Chez Kee v. PP [2008] 3 SLR(R) 447 at [113] but was recently reaffirmed by the Court of Appeal in Norasharee bin Gous v. PP [2017] 1 SLR 820.

${ }^{124}$ See discussion on accountability of police officers above.

${ }^{125}$ s. 24 CPC. See generally Tan, 2007, vol. 1, ch. IV.

${ }^{126}$ This is only applicable to arrestable offences (formerly called seizable offences). See Muhammad bin Kadar v. PP [2011] 3 SLR 1205 at [42] (Court of Appeal).
} 
knows of the facts and circumstances of the case. But this is qualified by the privilege against self-incrimination; he has the right not to make any statement that might 'have a tendency to expose him to a criminal charge or to a penalty or forfeiture.' ${ }^{127}$ A statement taken from the accused under this section is popularly known as a 'long statement'. Section 22(3) requires the statement to be (a) in writing; (b) read over to the accused; (c) if he does not understand English, interpreted for him in a language that he understands; and, (d) signed by him.

When the police finally decides to charge or proceed against a person, they must follow the procedure set out in section 23. They must read out a notice to the person. The notice will set out the charge, invite the person to make a statement and contain the caution that if the person withholds any facts relevant to his defence and raises them only at the trial, the trial judge may be less likely to believe him. A statement recorded under this section is popularly known as the 'cautioned statement'. This statement, again, must be (a) in writing; (b) read over to him; (c) if he does not understand English, interpreted for him in a language that he understands; and, (d) signed by him. ${ }^{128}$ The police may continue to question and take a 'long' statement from a person under section 22 even after he has been charged or proceeded against under section 23. ${ }^{129}$

\subsection{The Privilege Against Self-incrimination and the Right of Silence}

As noted, the suspect has the privilege against self-incrimination when questioned by the police. However, this privilege has been weakened in a number of ways. First, the police do not need to inform the suspect that he has this right. ${ }^{130}$ That the suspect was not told, prior to making a statement, of his privilege against self-incrimination does not affect its admissibility. ${ }^{131}$ Secondly, as already noted, the police may and often do deny the suspect access to a lawyer before the completion of investigation. As such, the suspect who is being interrogated, unless himself legally-trained, would

\footnotetext{
${ }^{127}$ s. 22(2) CPC. The legal position is different under the Prevention of Corruption Act, Cap. 241, 1993 rev. ed., s 27 of which gives investigating officers the power to require a person 'to give... information' relating to corruption cases. And s. 27 further provides that the person so questioned is 'legally bound to give that information'. In Taw Cheng Kong v. PP, the Singapore High Court held that a person who is being questioned under s. 27 is 'not entitled to refuse to answer incriminating questions'. (See also s. 75 of the Competition Act, Cap. 50B, 2006 rev. ed.).

${ }^{128}$ s. 23(3) CPC.

${ }^{129}$ s. 22(1). See also Mohamed Bachu Miah v. PP [1992] 2 SLR(R) 783 at [65].

${ }^{130} P P$ v. Mazlan bin Maidun [1992] 3 SLR(R) 968. In the past, the police had to inform the suspect of his right not to say anything before questioning him. This duty was set out in rules 3, 4 and 5 of Schedule E to the Criminal Procedure Code (Cap 113, 1970 rev. ed.). The Schedule was repealed in 1976. See Mohamed Bachu Miah v. PP [1992] 2 SLR(R) 783 at [43], [48].

${ }^{131}$ s. 258(3), Explanation 2(c), (d) CPC.
} 
likely not know that he has the privilege against self-incrimination. ${ }^{132}$ Thirdly, the judge may draw an adverse inference against the accused from his failure to disclose to the police facts he subsequently relies upon in his defence at the trial. ${ }^{133}$ This adverse inference may be drawn not just from an omission to mention relevant fact in a cautioned statement obtained under section 23 but also from an omission to do so in a statement given under section 22 (at least those that were taken on occasions subsequent to the person having been cautioned under section 23). ${ }^{134}$ Trial judges have not been reluctant to draw adverse inferences against accused persons for not disclosing material facts to the police. ${ }^{135}$

The risk of an adverse inference being drawn from silence provides strong inducement for the accused to speak. It may be argued that the section 23 notice and the power to draw adverse inferences from silence do not undermine the right against self-incrimination as they merely encourage the suspect to make early disclosure of exculpatory facts - which are facts supporting his defence as opposed to facts revealing his guilt. ${ }^{136}$ But the practical reality is that the suspect is induced to incriminate himself. The suspect may not fully understand the notice. At this stage, he has no access to a lawyer and since the beginning of 2011 , the police no longer have a legal duty to explain the notice to him. ${ }^{137}$ He may form the mistaken impression that he is required to disclose everything that he knows about the case. Further, the 'exculpatory information may well be inextricably linked with self-incriminating information. ${ }^{138}$ It must also be remembered that some defences, such as provocation, works as a 'confession and avoidance'. To raise such a defence is already to confess to the elements of the offence. The suspect may not be aware that it is for the prosecution to prove the elements of the crime beyond reasonable doubt. The section 23 notice and the power to draw an adverse inference from the suspect's silence have the effect of weakening the right not to speak and the right to put the prosecution to proof at a trial. ${ }^{139}$

The current position has been defended by drawing on strands of crime control ideology. Singapore's political leaders have been praised for having 'the political will to enact an appropriate framework to achieve' 'a relatively safe and secure environment that is free from crime'. This includes the introduction of the power to

\footnotetext{
${ }^{132}$ See Ho, 2013.

${ }^{133}$ s. 261 CPC.

${ }^{134}$ The power to draw such adverse inferences 'as appear proper' is provided for in s. 261(1) CPC. It is controversial whether an adverse inference may be drawn from an omission to mention relevant facts in a statement taken by the police under s. 22 prior to action being taken against the accused under s. 23. See Ho, 2013; Pinsler, 2017 at 221-226.

${ }^{135}$ See, eg, Yeo, 1983; Tan, 1997.

${ }^{136}$ Kwek Seow Hock v. PP [2011] 3 SLR 157 at [18], [19].

${ }^{137}$ Prior to 2011 , the police was required to explain the notice to the accused. On the practical difficulties that this created for the police, see Tsang Yuk Chung v. PP [1990] 2 SLR(R) 39 at [27], [28].

${ }^{138}$ Choo, 2013 at 102.

${ }^{139}$ See Philips, 1981 at [4.35], [4.37], [4.51], [4.52].
} 
draw adverse inferences from silence. ${ }^{140}$ The changes to the law show a shift from 'adherence to due process' towards 'crime control... values'. ${ }^{141}$ It is also claimed that they have 'greatly assisted... law enforcement agencies in investigating offences, leading to many more factually guilty persons being convicted through guilty pleas or convictions at trial. ${ }^{142}$ This claim does not appear to be supported by the available empirical studies. ${ }^{143}$

\subsection{Rules on Admissibility of Evidence}

The legal rules on the admissibility of evidence are to be found mainly in the EA and the CPC. They are, broadly speaking, variations of rules that exist at common law. Thus, the admissibility of evidence is subject to the hearsay rule, character and similar facts rule, and so forth. Statements obtained from the accused by the police are admissible under section 258(1) CPC provided certain conditions are met. First, the statement must have been obtained by a police officer of the rank of sergeant and above. ${ }^{144}$ Secondly, as discussed below, the statement must not have been obtained by applying undue pressure and the court has a limited discretion to exclude the statement on the ground of prejudice.

\section{Exclusion of Evidence Obtained by Torture}

\subsection{Definition of Torture}

There does not appear to be any domestic statute that defines torture. ${ }^{145}$ The definition of torture in Article 1 of the Convention against Torture, and Other Cruel, Inhuman, or Degrading Treatment or Punishment (see also below, 'Effect of

\footnotetext{
${ }^{140}$ Chan, 2006 at 13 .

${ }^{141}$ Ibid at 14 .

${ }^{142}$ Ibid at 15. See also Chan, 1996 at 444.

${ }^{143}$ In one study published in 1986, the author concluded from an examination of crime statistics that the 1976 amendments were not 'perceived by potential offenders as sufficiently increasing their risk of detection to deter them from crime' and that 'there was no visible decrease in the crime rate after the amendments were introduced': Mohan, 1986 at xxxiv. An earlier study by Yeo, 1983 at 100-101, concluded that 'the amendments have not materially assisted the Singapore police force and prosecuting officers in their combat against crime'. It is noted by Tan, 1997 at 480, that '[e]mpirically, it is less than certain whether the existence of the silence provisions and the courts' invocation of these have truly resulted in accused persons speaking up more readily today than they would have done in the past.'

${ }^{144}$ s. 258(2) CPC.

${ }^{145}$ Yong Vui Kong v. PP [2015] 2 SLR 1129 at [77] (the Act cited by counsel for the appellant does not in fact contain any definition of torture).
} 
International Law (Human Rights)) and decisions of international courts were considered by the Court of Appeal in Yong Vui Kong $v$ PP. ${ }^{146}$ (What fell for decision in this case was the constitutionality of caning as a form of criminal punishment which is not relevant for present purposes.) The Court of Appeal came to the conclusion 'that to determine whether particular conduct constitutes torture entails a fact-sensitive inquiry that requires a holistic analysis of the purpose of the conduct, the manner of its execution and its effect on the recipient. ${ }^{, 147}$

\subsection{Prohibition Against Torture and the Exclusion of Evidence Obtained by Torture}

There is no express prohibition against torture in the Constitution and no provision explicitly requiring exclusion of evidence obtained by torture. However, article 9(1) of the Constitution protects against deprivation of 'life or personal liberty save in accordance with law'. In Yong Vui Kong $v P P,{ }^{148}$ the appellant relied, among other things, on the common law prohibition against torture, citing in support the House of Lords judgment in A v Secretary of State for the Home Department (No.2). ${ }^{149}$ It was argued that this common law rule has constitutional force as a fundamental rule of natural justice included in the term 'law' in article 9(1). The Court of Appeal agreed 'that there is a common law prohibition against torture, and that this prohibition has been imported into domestic law pursuant to...Art 162 of the Constitution'. ${ }^{150}$ However, 'the common law prohibition of torture does not prohibit caning or any other form of corporal punishment." ${ }^{151}$ It 'has a narrow and specific compass', is 'concerned with the practice of torturing suspects or witnesses for the purpose of extracting evidence and confessions' and does not 'cover the treatment of criminals after they were found guilty of their crimes. ${ }^{152}$ The Court of Appeal went on to state ${ }^{153}$ :

The fundamental rules of natural justice in the common law are ... procedural rights aimed at securing a fair trial. Torture in its narrow sense (where it is used to extract evidence to be used as proof in judicial proceedings) would violate the fundamental rules of natural justice; to convict a person based on evidence procured by torture strikes at the very heart of a fair trial.

\footnotetext{
${ }^{146}$ Yong Vui Kong v. PP [2015] 2 SLR 1129 at [79] et seq.

${ }^{147}$ Ibid at [89].

${ }^{148}$ Yong Vui Kong v. PP [2015] 2 SLR 1129.

${ }^{149}$ A v. Secretary of State for the Home Department (No.2) [2006] 2 AC 221.

${ }^{150}$ Yong Vui Kong v. PP [2015] 2 SLR 1129 at [58]. Article 162 states that all existing laws shall continue in force on and after the commencement of the Constitution but they shall be construed in conformity with the Constitution. The common law rule on torture pre-dates the commencement of the Constitution.

${ }^{151}$ Yong Vui Kong v. PP [2015] 2 SLR 1129 at [60].

${ }^{152}$ Ibid at [59].

${ }^{153}$ Ibid at [64].
} 
This passage suggests that the common law rule which renders evidence obtained by torture strictly inadmissible is part of Singapore law and has constitutional status. However, this was only an obiter dictum as the case itself was concerned with the constitutionality of caning.

This common law rule is of practical significance only in relation to evidence obtained from a third party by torture. This is because a statement obtained from the accused person by torture would be inadmissible anyway under the voluntariness rule or the oppression doctrine, both of which are examined in the next section.

\section{Exclusion of Statements Obtained from the Accused by Undue Pressure ${ }^{154}$}

That courts tend to give a lot of weight to confession evidence makes it all the more important for the police to obtain such evidence. The police might be tempted to go after a confession as a short-cut and at the expense of seeking out independent evidence. ${ }^{155}$ It is necessary to have legal rules that protect against the risk of confessions being obtained by undue pressure. To those rules we now turn.

\subsection{Voluntariness as a Condition of Admissibility}

A statement obtained by the police from the accused is inadmissible if the prosecution is unable to satisfy the so-called 'voluntariness test' in section 258(3) CPC. This provision, which was previously in the EA, has been in existence since the passing of the EA in 1893; it is expressed in technical and archaic language. Under this test, the court must exclude a statement if the accused was caused to give it by any 'inducement, threat or promise' proceeding from a 'person in authority'. Where no inducement was in fact made, and the accused was labouring under a self-generated false impression of an inducement, this exclusionary rule would not apply. ${ }^{156}$ The prototypical 'person in authority' is the law enforcement officer conducting the interrogation. ${ }^{157}$ Another requirement is that the inducement, threat or promise must be sufficient to give the accused grounds which would appear to

\footnotetext{
${ }^{154}$ For greater details, see Ho, 2016.

${ }^{155}$ 'Parliamentary Debates Singapore: Official Report', vol. 69 (1 June 1998) at col. 104 (Mr J B Jeyaretnam): 'the confession in many cases is the shortcut method[.] It spares the investigating officer from having to go and make minute, detailed investigations and to look for corroborative evidence. So he has an interest in, if it is possible, getting an accused person to admit to the offence.'

${ }^{156}$ Lu Lai Heng v. PP [1994] 1 SLR(R) 1037 (the inducement was 'self-perceived').

${ }^{157}$ Under certain circumstances, the interpreter assisting in the questioning is also a person in authority: PP v. Lim Boon Hiong [2010] 4 SLR 696.
} 
him reasonable for supposing that he stands to gain an advantage if he makes the statement or suffer some 'evil' (that is, harm) if he does not give it. ${ }^{158}$ (Read literally, the provision requires the inducement, threat or promise to have reference to the charge against the accused and the benefit to be gained or harm to be avoided must be in reference to the proceedings against him. But courts have not insisted on these requirements. Thus a statement obtained under a threat to forfeit property owned by relatives of the accused is also inadmissible. ${ }^{159}$ )

A statement is not rendered inadmissible merely by the fact that it was made 'under a promise of secrecy, or in consequence of a deception practised on the accused for the purpose of obtaining it ${ }^{160}$ or "when the accused was intoxicated ${ }^{161}$ In 2010, various MPs ${ }^{162}$ and lawyers ${ }^{163}$ objected to these provisions. The thrust of their argument was that a statement made under such circumstances cannot be said to be voluntary or reliable. But the government could not be persuaded to change the law.

\subsection{Doctrine of Oppression}

At one time, bad treatment of a suspect in the course of obtaining his statement—at least where it falls short of torture - was not considered capable, without a specific threat, inducement or promise, of rendering the statement inadmissible. Oppression came later to be accepted as a ground for exclusion. It was treated as having been 'subsumed' in the statutory voluntariness rule discussed in the preceding section. ${ }^{164}$ English common law authorities on the definition of oppression were followed. ${ }^{165}$

\footnotetext{
${ }^{158}$ That the test of voluntariness was formulated in the late nineteenth century explains the archaic language of the section. There is a further requirement that the 'inducement, threat and promise', and the 'advantage' or 'evil', must have reference to the charge. But the courts have not insisted strictly on this requirement: see Poh Kay Keong v. PP [1995] 3 SLR(R) 887; Chai Chien Wei Kelvin v. PP [1998] 3 SLR(R) 619 at [55] (a promise to let the accused call his wife was held not to have 'reference to the charge').

${ }^{159}$ Poh Kay Keong v. PP [1995] 3 SLR(R) 887.

${ }^{160}$ s. 2583(3) Explanation 2(a) CPC.

${ }^{161}$ s. 2583(3) Explanation 2(b) CPC.

${ }^{162}$ See 'Parliamentary Debates Singapore: Official Report', vol. 87 (18 May 2010) (speeches of Mr K Shanmugam, Mr Alvin Yeo, Mr Michael Palmer, and Mr Hri Kumar Nair) and 'Parliamentary Debates Singapore: Official Report', vol. 87 (19 May 2010) (speeches of Mr Lim Biow Chuan and Mr K Shanmugam). Debates on this issue were extensively reported: see, eg, 'Can confession of a drunk person count as evidence', The Straits Times, 19 May 2010 and 'Intoxication issue gets another airing', The Straits Times, 20 May 2010.

${ }^{163} \mathrm{See}$, eg, views of Mr Subnas Anandan, president of the Association of Criminal Lawyers of Singapore, and Mr Edmond Pereira, a defence lawyer, as reported in 'Criminal lawyers concerned over clause in proposed criminal procedure code', Today, 17 May 2010.

${ }^{164}$ Gulam bin Notan Mohd Shariff Jamalddin v. PP [1999] 1 SLR(R) 498 at [53].

${ }^{165}$ See, eg, Gulam bin Notan, ibid; Chai Chien Wei Kelvin v. PP [1998] 3 SLR(R) 619 at [56]-[59].
} 
According to that definition, oppression 'imports something which tends to sap, and has sapped, that free will which must exist before a confession is voluntary. ${ }^{166} \mathrm{In}$ determining whether there was oppression, the court will look at the full circumstances, including length of time of questioning, period of rest, the provision of refreshment and the character of the person being questioned. In 2011, oppression as a ground for exclusion received explicit statutory recognition with the introduction of Explanation 1 to section 258(3) CPC. ${ }^{167}$ Oppressive treatment will render the accused's statement inadmissible even in the absence of an "overt act from a person in authority such as a specific threat, inducement or promise". ${ }^{168}$ However, bad treatment by the police must be very egregious for the doctrine of oppression to apply. This doctrine is seldom applied by the court.

Extremely taxing interrogation can amount to oppression. For example, in Public Prosecutor v Lim Kian Tat, ${ }^{169}$ one of the statements was 'taken during an 18-hour interrogation with an hour's break. It was taken during the fourth night in a row in which the accused did not have any adequate sleep.' The High Court was 'satisfied that the accused had spoken, after the police had rejected his earlier versions, and had spoken when he would not have otherwise' and concluded that the statement was 'made in circumstances where there was oppression. ${ }^{170}$

The failure to provide sustenance over a long period may also, depending on the circumstances, amount to oppression. In Fung Yuk Shing v Public Prosecutor, ${ }^{171}$ the suspect had been deprived of food and drink for about 7 hours when his statement was taken. The trial judge held that this amounted to oppression. On appeal, the Court of Appeal expressed disagreement. ${ }^{172}$ According to the Court of Appeal, whether deprivation of sustenance is sufficiently serious to justify exclusion of the evidence will depend on the circumstances of the case. The criminal bar has called for greater legal regulation of the recording process. For example, in his speech at the opening of the legal year in 2008, the President of the Singapore Law Society, Mr. Michael Hwang, reported 'a longstanding and widespread feeling at the Bar that legislation (or at least a protocol) is needed to prescribe how... statements... are recorded' by the police. ${ }^{173}$ Similarly, Mr Sant Singh SC, a defence

\footnotetext{
${ }^{166} R$ v. Priestley (1967) $51 \mathrm{Cr}$ App R 1 at $1 ; R$ v. Prager [1972] 1 WLR 260 at 266.

${ }^{167}$ See Chin, 2012 at $78-84$.

${ }^{168}$ Tey Tsun Hang v. PP [2014] 2 SLR 1189 at [91].

${ }^{169}$ Public Prosecutor v. Lim Kian Tat [1990] 1 SLR(R) 273.

${ }^{170}$ Ibid at [29].

${ }^{171}$ Fung Yuk Shing v. Public Prosecutor [1993] 2 SLR(R) 92.

${ }^{172}$ Fung Yuk Shing v. PP [1993] 2 SLR(R) 771.

${ }^{173}$ 'Address of the President of the Law Society - Opening of the Legal Year 2008', 5 January 2008, at [9], available online at $<$ https://www.supremecourt.gov.sg/news/speeches/opening-oflegal-year-2008 — address-by-the-president-of-the-law-society-of-singapore>, accessed 31 October 2018. See also Hwang, 2010, which was reported in 'Set rules for police interrogation', The Straits Times, 25 June 2010.
} 
lawyer who has considerable experience as a former police inspector and deputy public prosecutor, has urged that 'provisions... be enacted to put in place a protocol for the recording of statements from accused persons'. ${ }^{174}$

\subsection{Burden of Proof}

When admissibility is contested, it is for the prosecution to prove beyond reasonable doubt that the accused gave his statement voluntarily and without oppression. ${ }^{175}$ The burden of proof is not as difficult to discharge as it may seem. ${ }^{176}$ One reason for this might be judicial pragmatism. This can be detected, for instance, in judgment of the Court of Appeal in Panya Martmontree $v$ Public Prosecutor. ${ }^{177}$ While acknowledging that the accused need not do more than raise a reasonable doubt as to the voluntariness of his statement, the Court of Appeal added that this did not mean that 'the slightest suspicion of an inducement, threat or promise or of an assault [was] sufficient to rule out a statement'. ${ }^{178}$ The Court of Appeal was sensitive to the fact that '[t]he police work in difficult circumstances. If they are required to remove all doubt of influence or fear, they would never be able to achieve anything. ${ }^{179}$ This message was reiterated in Yeo See How v Public Prosecutor $^{180}$ where the Court of Appeal took the position that 'there is no necessity... for interrogators to remove all discomfort. Some discomfort has to be expected - the issue is whether such discomfort is of such a great extent that it

\footnotetext{
${ }^{174}$ Interview published in Inter Se, January 2009 at 10, 11. A similar call was made by Judicial Commissioner Amarjeet Singh: 'Code of practice needed for police questioning —JC', The Straits Times, 5 November 1995. See also: Singh, 2006; 'Parliamentary Debates Singapore: Official Report', vol. 69 (1 June 1998) at cols. 78 and 104 (Mr J B Jeyaratnam); The Law Society of Singapore, 'Report of the Council of the Law Society on the Draft Criminal Procedure Code Bill 2009' (17 February 2009) at [3.7]-[3.9], available online at: <https://www.lawsociety.org.sg/ Portals/0/MediaAndResourceCentre/FeedbackinPublicConsultations/ReportofCouncilLawSociety DraftCPCBill2009.pdf>, accessed 31 October 2018.

${ }^{175}$ PP v. Lim Boon Hiong [2010] 4 SLR 696 at [36].

${ }^{176}$ See 'Parliamentary Debates Singapore: Official Report', vol. 69 (1 June 1998) at cols. 86, 87 ('[T]he courts admit almost all the statements. The courts find it difficult to believe that police officers would resort to the conduct [of ill-treating suspects for the purpose of extracting a confession].') Similarly, a different member of Parliament noted during the second reading of the CPC Bill on 19 May 2010 that when it comes to challenging the admissibility of his statement, it often boils down to the word of the accused against the word of the investigating officer. 'Unfortunately, the Courts would invariably believe the Investigating Officer. The odds are usually stacked against the accused person.' 'Parliamentary Debates Singapore: Official Report', vol. 87 (19 May 2010) at cols. 86, 87, 549 .

${ }^{177}$ Panya Martmontree v. Public Prosecutor [1995] 2 SLR(R) 806.

${ }^{178}$ Ibid at [32].

${ }^{179}$ Ibid at [29].

${ }^{180}$ Yeo See How v. Public Prosecutor [1996] 2 SLR(R) 277 at [40]. See also PP v. Ng Pen Tine [2009] SGHC 230 at [20]; Tey Tsun Hang v. PP [2014] 2 SLR 1189 at [114].
} 
causes the making of an involuntary statement'. The pragmatism discernible in these statements carries the risk of confusing the standard of proof (which goes to our knowledge of the disputed facts) and policy considerations that relate to the kinds or levels of pressure that should be judicially tolerated.

\subsection{Discretion to Exclude Wrongfully Obtained Statements}

There is a difference between inadmissibility as a matter of law and discretionary exclusion. A statement obtained by means of a threat, an inducement or a promise, or by oppression, is inadmissible under the legal rules discussed above. This means that the court must exclude it. ${ }^{181}$ Even in the absence of any of these vitiating factors, and even when there is no rule of law that renders the statement strictly inadmissible, the court has discretion to exclude it in exceptional circumstances. There are three major groups of relevant cases.

One group involves entrapment. While it was previously acknowledged that there is some discretion to exclude evidence if it was obtained in an entrapment, this view has since been repudiated on the basis that such evidence will invariably be more probative than prejudicial. ${ }^{182}$ Entrapment, it seems, cannot be a ground for discretionary exclusion.

Another group consists of cases where a statement was taken from the suspect while he was suffering from symptoms of drug withdrawal or suffering from the effects of drugs or medication. The scenario that arose in Garnam Singh v PP is a fairly typical one. ${ }^{183}$ The accused was charged with drug trafficking. He gave incriminating statements to the investigating law enforcement officers. At the trial, he sought to have the statements excluded. The accused argued that his statements were not voluntarily given because he was a heavy user of drugs and at the time that he gave the statements, he was suffering from severe withdrawal symptoms. This argument was rejected by the Court of Appeal. It held that in order to justify exclusion, the suspect 'must be in a state of near delirium' such that 'his mind did not go with the statements he was making. Such, however, was not the case here. ${ }^{184}$ This test was found to be satisfied, and the affected statement excluded, in a subsequent case. ${ }^{185}$ A distinguishing feature was that the statement was taken while the effect of drug was at its peak. The legal basis for exclusion in this kind of scenario is involuntariness of some sort and appears to be discretionary.

\footnotetext{
${ }^{181} P P$ v. Ismil bin Kadar [2009] SGHC 84 at [19].

${ }^{182}$ See Cheng Swee Tiang v. PP [1964] MLJ 291; Law Society of Singapore v. Tan Guat Neo Phyllis [2008] 2 SLR(R) 239.

${ }^{183}$ Garnam Singh v. PP [1994] 1 SLR(R) 1044.

${ }^{184}$ Ibid at [31].

${ }^{185}$ PP v. Dahalan bin Ladaewa [1995] 2 SLR(R) 124 at [74] (upheld by Court of Appeal in PP v. Dahalan bin Ladaewa [1995] SGCA 87).
} 
The third group of cases involves failure to comply with the prescribed procedure in the taking of a statement. This will generally not have the consequence of rendering the statement strictly inadmissible. ${ }^{186}$ The courts have not demanded strict adherence to the legally prescribed procedure as a condition of admissibility. For example, in Panya Martmontree v Public Prosecutor, ${ }^{187}$ the Court of Appeal held that even though the disputed statement (which was taken by the police under the precursor of the current section 22 of the CPC) was not read back to the accused or signed by him, it remained admissible. Since 2011, this judicial approach of not allowing procedural lapses to result in strict inadmissibility has been statutorily endorsed. ${ }^{188}$

But this still leaves the possibility of discretionary exclusion in extreme cases of flagrant disregard of the applicable procedure. This discretion is a narrow one. In exercising the discretion, the judge has to weigh its likely prejudicial effect if it is admitted against the probative value of the evidence. The leading authority is Muhammad bin Kadar v Public Prosecutor. ${ }^{189}$ Among other features that the court found disturbing, the statements were formally transcribed only hours after the questioning, and they were not read back or signed by the accused. No acceptable explanation was offered for these lapses. The Court of Appeal held that the statements should have been excluded by the trial judge in the exercise of his discretion.

The judgment contains a number of key rulings. First, it was held that the court has 'a common law discretion to exclude voluntary statements that would otherwise be admissible... where the prejudicial effect of the evidence exceeds its probative value' ${ }^{190}$ This discretion can be traced to the English (House of Lords') decision in $R v$ Sang. ${ }^{191}$

Secondly, the court should not exclude a statement in the exercise of this discretion merely because of the manner in which it was obtained. It is proper to exercise this discretion only where the procedural breach results in the evidence being more prejudicial than probative. The Court of Appeal expressly disavowed any disciplinary function in the discretion. The exclusion of evidence is not to "discipline the wrongful behaviour of police officers... or the Prosecution."192 Nevertheless, the exclusion of evidence may have the incidental effect of removing

\footnotetext{
${ }^{186}$ See s. 358(3), Explanation 2(e), CPC.

${ }^{187}$ Panya Martmontree v. Public Prosecutor [1995] 2 SLR(R) 806 at [6]. The Court of Appeal cited an earlier unreported judgment of the Court of Appeal in Vasavan Sathiadew v. PP [1992] SGCA 26. See also Tsang Yuk Chung v. PP [1990] 2 SLR(R) 39 at [13]-[17] (a statement obtained under the precursor of s. 23 CPC was held to be admissible even though the prescribed notice containing the charge was not explained to the accused).

${ }^{188}$ s. 258(3), Explanation 2(e), CPC.

${ }^{189}$ Muhammad bin Kadar v. PP [2011] 3 SLR 1205. On the evolution of the discretion, see Ho, 2012.

${ }^{190}$ Ibid at [53].

${ }^{191} R$ v. Sang [1980] AC 402.

${ }^{192}$ Muhammad bin Kadar v. PP [2011] 3 SLR 1205 at [68].
} 
'the incentive for [future] non-compliance on the part of police officers.' This will help ensure that all evidence in the form of written statements coming before the court will be as reliable as possible. ${ }^{193}$

Thirdly, the governing procedures are important safeguards of reliability. A serious breach of the relevant rules may undermine the reliability of the recorded statement, resulting in the evidence having low probative value. ${ }^{194}$ At the same time, the prejudicial effect of the evidence may be high in the sense that admitting the statement will expose the accused to the risk of the evidence being given more weight than it deserves. The risk comes from the general aura of reliability possessed by formal statements recorded by the police. This aura of reliability is misleading where the statement was not obtained, as it should have been done, 'under a set of strict procedures strictly observed by a trustworthy officer well-trained in investigative techniques. ${ }^{195}$

Fourthly, if the prosecution seeks to admit in evidence a statement obtained by a police officer in violation of the relevant rules and procedure, the prosecution bears the burden of proving that the evidence is more probative than prejudicial. To show that the evidence is probative, the prosecution will have to offer some reasonable explanation for the procedural irregularity that is sufficient to re-establish confidence in the reliability of the statement. ${ }^{196}$ The more deliberate or reckless the non-compliance, the more difficult it will be for the prosecution to offer a sufficiently cogent explanation. ${ }^{197}$

Applying these principles to the present case, the Court of Appeal doubted the bona fide of the investigating officer and the accuracy of the statements recorded by him. His procedural non-compliance was deliberate and not due to carelessness or operational necessity. ${ }^{198}$ No plausible explanation was given for the 'manifest irregularities'. ${ }^{199}$ The prosecution failed to show that the probative value of the statements outweighed their prejudicial effect. Hence, the trial judge ought to have excluded both statements in the exercise of his discretion.

One commentator reads this decision and other developments as heralding 'an impending spring' where we will see 'the use of broader and more abstract values like fairness to effect subtle changes in judicial attitudes' ${ }^{200}$ There is as yet no known judgment in which the court has cited Muhammad bin Kadar and exercised the discretion against the prosecution.

\footnotetext{
${ }^{193}$ Ibid at [68].

${ }^{194}$ Ibid at [56].

${ }^{195}$ Ibid at [58].

${ }^{196}$ Ibid at [61].

${ }^{197}$ Ibid at [62].

${ }^{198}$ Ibid at [140].

${ }^{199} \mathrm{Ibid}$ at [147].

${ }^{200}$ Hor, 2013 at $849,872$.
} 


\section{Admissibility and Effect of Derivative Evidence}

There is no 'fruit of the poisonous tree' doctrine in Singapore. A different doctrine exists. It is sometimes called the doctrine of 'confirmation by discovery of subsequent fact'. This doctrine is provided for in section 258(6)(c) CPC which states: 'when any fact or thing is discovered in consequence of information received from a person accused of any offence in the custody of any officer of a law enforcement agency, so much of such information as relates distinctly to the fact or thing thereby discovered may be proved.' This doctrine was applied in PP v Chin Moi Moi ${ }^{201}$ The accused, a saleswoman, was charged with theft of a gold bangle from a customer's flat. In her police statement, she stated, amongst other things, that she took the bangle and threw it out of the flat's window. But the accused claimed that she was forced to sign the statement and that she had been threatened, harassed and abused. The trial judge excluded the statement. On appeal, the prosecution relied on the fact that the statement had led the police to the field at the bottom of the flat where, after a search, they found the gold bangle. According to the High Court hearing the appeal, this meant that the prosecution should have been allowed to admit in evidence that part of her statement where she stated: 'Without much hesitation, I throw down... the gold bangle out of the kitchen window...' The truth of this part of her statement was, as it were 'confirmed', by the discovery of the gold bangle at the place where it was found. 'The rationale for the admissibility of that part of the statement which is subsequently confirmed by the discovery of a material fact is that it must be reliable'. ${ }^{202}$

\section{Effect of International Law on Human Rights}

\subsection{International/Human Rights Law}

Singapore has thus far ratified four international human rights treaties. ${ }^{203}$ However, she is not a party to the International Covenant on Civil and Political

\footnotetext{
${ }^{201}$ PP v. Chin Moi Moi [1994] 3 SLR(R) 924. The court applied s. 27 EA which, until it was replaced by s. 258(6)(c) CPC in 2011, was where the doctrine was to be found.

${ }^{202}$ PP v. Chin Moi Moi [1994] 3 SLR(R) 924 at [22]. This doctrine is rejected by English common law as the exclusion of improperly obtained evidence is 'not dependent only upon possible unreliability but also upon the principle that a man cannot be compelled to incriminate himself and upon the importance that attaches in a civilised society to proper behaviour by the police towards those in their custody': Lam Chi-Ming v. R [1991] 2 AC 212 at 220.

${ }^{203}$ They are (with year of ratification within brackets): Convention on the Elimination of All Forms of Discrimination against Women (1995), Convention on the Rights of the Child (1995), Optional Protocol to CRC on the involvement of children in Armed Conflict (2008); and Convention on the Rights of Persons with Disabilities (2013).
} 
Rights $^{204}$ or the Convention against Torture, and Other Cruel, Inhuman, or Degrading Treatment or Punishment (CAT). ${ }^{205}$

She is however a party to the ASEAN Human Rights Declaration, ${ }^{206}$ article 14 of which states 'No person shall be subject to torture or to cruel, inhuman or degrading treatment or punishment'. Singapore is a member of the United Nations. The Universal Declaration of Human Rights (UDHR) was adopted by the United Nations in $1948 .^{207}$ Under Article 5 of the UDHR, 'No one shall be subjected to torture or to cruel, inhuman or degrading treatment or punishment.' Singapore has ratified the Convention on the Rights of Persons with Disabilities; article 15 of this Convention provides that 'No one shall be subjected to torture or to cruel, inhuman or degrading treatment or punishment.'

While the provisions in the above paragraph prohibit torture, they do not address the issue of the admissibility of evidence obtained by torture. In contrast, this issue is explicitly dealt with in article 15 of the CAT which prohibits the use as evidence of any statement obtained by torture. Although Singapore is not a party to the CAT, as noted earlier, evidence obtained by torture is likely to be treated as inadmissible.

\subsection{Universal Periodic Review}

Singapore has participated twice in the Universal Periodic Review (UPR). The UPR is conducted under the auspices of the United Nations' Human Rights Council for the purpose of reviewing the human records of member states. The first UPR of Singapore was conducted in 2011 and the second in 2016.

In the National Report submitted for the 2011 UPR, the government drew attention to the fact that the Singapore Constitution 'guarantees due process and fair trial, including prohibiting ... evidence obtained by means of torture'. ${ }^{208}$ It is an offence 'for anyone to cause hurt to or wrongfully confine a person for the purpose of extorting a confession or any information, which may lead to the detection of an offence'. ${ }^{209}$ There is a need to subject 'individual rights...to legal limits in order to protect the rights of others, as well as to maintain public order and general welfare. ${ }^{210}$

\footnotetext{
${ }^{204}$ Adopted and opened for signature, ratification and accession by the General Assembly resolution 2200A (XXI) of 16 December 1966, entry into force 23 March 1976, in accordance with Article 49. Article 7 of the ICCPR reads: 'No one shall be subjected to torture or to cruel, inhuman or degrading treatment or punishment.'

${ }^{205}$ Adopted and opened for signature, ratification and accession by General Assembly resolution 39/46 of 10 December 1984; entry into force 26 June 1987, in accordance with article 27(1).

${ }^{206}$ Adopted by the ASEAN Member States at Phnom Penh, Cambodia, on 18 November 2012.

${ }^{207}$ By General Assembly Resolution 217A on 10 December 1948.

${ }^{208}$ 'National report submitted in accordance with paragraph 15 (a) of the annex to Human Rights Council resolution 5/1' (2 February 2011) at [23], available online at <http://www.ohchr.org/EN/ HRBodies/UPR/Pages/SGindex.aspx>, accessed 31 October 2018.

${ }^{209}$ Ibid at [122].

${ }^{210}$ Ibid at [110].
} 
The section of the Report on criminal justice stresses that 'it is a fundamental human right of all citizens to live in a safe environment, free from drugs, guns, random street violence and terrorism. ${ }^{211}$ The laws in Singapore 'are designed to protect the public against crimes, while ensuring that persons accused of alleged crimes have due process and fair trials. Singapore's crime rate is one of the lowest -684 per 100,000 population in 2008, with 111 violent crimes per 100,000 population — despite a relatively small police force. ${ }^{212}$

Inputs from NGOs were sought as part of the UPR process. A Human Rights NGO (MURUAH Singapore) raised several features of Singapore's criminal process which they found to be troubling. These included the denial of access to counsel during police investigation and the permissibility of resting a criminal conviction solely on a confession recorded in the course of police interrogation. It noted that the defence often faced evidential difficulties in challenging the voluntariness of such confessions. ${ }^{213}$ According to the 2011 Report of the Working Group on the Universal Periodic Review of Singapore, ${ }^{214}$ Singapore did not support the recommendation by Canada to 'adopt new provisions to inform those detained of their right to counsel and guarantee their access to Counsel immediately upon arrest. ${ }^{215}$

In the 2015 National Report for the second UPR, ${ }^{216}$ the government reiterated that it considers 'the safety and security of the person to be a fundamental human right, without which other rights cannot genuinely be enjoyed. ${ }^{, 217}$ The priority of Singapore's criminal justice system is to 'deter crime and protect society against criminals. ${ }^{218}$ In its submission for the second UPR, MARUAH Singapore essentially repeated the observations and recommendations alluded to above. ${ }^{219}$ The Report of the Working Group makes little mention of criminal justice issues save on the topic of the death penalty. ${ }^{220}$

\footnotetext{
${ }^{211}$ Ibid at [119].

${ }^{212}$ Ibid at [119].

${ }^{213}$ 'Universal Periodic Review - Singapore - Submission of MURUAH (Working Group for an ASEAN Human Rights Mechanism, Singapore)' (2011) at [6], available online at <http://www. ohchr.org/EN/HRBodies/UPR/Pages/UPRSGStakeholdersInfoS11. aspx>, accessed 31 October 2018.

${ }^{214}$ 'Report of the Working Group on the Universal Periodic Review - Singapore' (11 July 2011), available online at <http://www.ohchr.org/EN/HRBodies/UPR/Pages/SGindex.aspx>, accessed on 31 October 2018.

${ }^{215}$ Ibid at [97.11].

${ }^{216}$ 'National report submitted in accordance with paragraph 5 of the annex to Human Rights Council resolution 16/21' (28 October 2015), available online at <http://www.ohchr.org/EN/ HRBodies/UPR/Pages/SGindex.aspx>, accessed 31 October 2018.

${ }^{217}$ Ibid at [100].

${ }^{218}$ Ibid at [101].

${ }^{219}$ 'MARUAH submission for Universal Periodic Review' (21 June 2015), available online at $<$ http://www.ohchr.org/EN/HRBodies/UPR/Pages/UPRSGStakeholdersInfoS24.aspx>, accessed 31 October 2018.

${ }^{220}$ 'Report of the Working Group on the Universal Periodic Review - Singapore' (15 April 2016), available online at <http://www.ohchr.org/EN/HRBodies/UPR/Pages/SGindex.aspx $>$, accessed 31 October 2018.
} 


\section{Safeguards $\mathbf{s}^{221}$}

One way of safeguarding the voluntariness and accuracy of confessions is to allow the suspect access to legal advice before or during police interrogation. As we have seen, this safeguard is generally unavailable in Singapore as the right to counsel is a restrictive one.

In an effort to spread knowledge of rights in the course of a criminal investigation, search or prosecution, the Law Society of Singapore, working with the Attorney-General Chambers and with the support of the Ministry of Law, published a four-page pamphlet containing relevant information for distribution to police centres, police posts and community clubs and centres. ${ }^{222}$ This pamphlet is available in the four official languages in Singapore. ${ }^{223}$ However, follow-up checks revealed that "some Investigating Officers had never heard of [the pamphlets], they were unavailable in a number of land divisions, and not available in the lockups where they were most needed". 224

An Appropriate Adult Scheme was introduced in $2015 .^{225}$ It allows a neutral third party who is a trained volunteer to be present during police questioning of a person with mental or intellectual disability. ${ }^{226}$ Since April 2017, the scheme has been extended to minors. ${ }^{227}$ This extension was made following the apparent suicide of a fourteen-year-old boy a few hours after his release by the police. ${ }^{228}$ He had been picked up from his school and questioned alone at a police station. ${ }^{229}$

\footnotetext{
${ }^{221}$ See generally Singh, 2006.

${ }^{222}$ See 'Pick up “pamphlet of rights' to get it right', The Straits Times, 11 April 2015.

${ }^{223}$ They are Malay, Mandarin, Tamil and English. See art. 153A of the Constitution of Singapore.

${ }^{224}$ This was reported by the President of the Law Society: Thio, 2016.

${ }^{225}$ See 'Help for Suspects with Special Needs', The Straits Times, 1 April 2015. The launch was preceded by a pilot run in 2013 .

${ }^{226}$ See 'Drug offenders with special needs to get support', The Straits Times, 18 January 2017.

${ }^{227}$ See 'Volunteers to offer minors support in police interviews', The Straits Times, 7 January 2017.

${ }^{228}$ See 'Parliamentary Debates Singapore: Official Report', vol. 94 (1 March 2016) (Minister for Home Affairs). See also 'Police to review the way youth are questioned', The Straits Times, 2 February 2016; 'Death of 14-year-old: Experts welcome police review on procedures for questioning youth', The Straits Times, 3 February 2016; 'Law Society sets up panel to study investigation protocols for young suspects', The Straits Times, 16 February 2016; 'Police review to consider three points', The Straits Times, 2 March 2016; 'Protecting minors suspected of crime', The Straits Times, 17 January 2017.

${ }^{229}$ The government strongly denied in Parliament that there was any police mistreatment: 'Parliamentary Debates Singapore: Official Report', vol. 94 (1 March 2016) (Minister for Home Affairs). See also 'No basis for hasty conclusion on boy's death: Shanmugam', The Straits Times, 2 March 2016.
} 
The role of the appropriate adult is not to give legal advice but to prevent miscommunication and enhance accuracy in the recording of statements. ${ }^{230}$ The scheme currently faces a shortage of volunteers. ${ }^{231}$

Another way to protect the voluntariness of statements is to have police interrogations video-recorded. The government had previously resisted repeated calls to implement a system of recording. ${ }^{232}$ In July 2015, the government finally agreed to launch a pilot programme of video recording starting in the first quarter of $2016 .^{233}$ This pilot project was welcomed by the legal profession. ${ }^{234}$ But it did not materialise due to a lack of 'appropriate legislative framework'. ${ }^{235}$ Legislative reform to allow video-recording is currently underway. ${ }^{236}$

\section{Statistics}

It is difficult to find access to relevant statistics. ${ }^{237}$ Below are some data obtained from indirect sources.

\footnotetext{
${ }^{230}$ The lawyer representing the suspect cannot serve as an Appropriate Adult under this scheme. See Lok, 2013.

${ }^{231}$ 'More volunteers needed to help young suspects', The Straits Times, 23 May 2017. As of 30 March 2017, the scheme has a pool of 143 volunteers: '143 volunteers ready to help young suspects', The Straits Times, 30 March 2017.

${ }^{232}$ See eg, Singh, 2006.

${ }^{233}$ See 'Police to try out videotaping interviews with suspects', The Straits Times, 23 July 2015. The pilot project was also mentioned by the Attorney-General, Mr V K Rajah, SC, in his speech delivered at the Opening of the Legal Year 2016 (11 January 2016), available online at: <https:// www.agc.gov.sg/docs/default-source/speeches/2016/ag's-oly-speech-2016-(as-delivered)-(4).pdf? sfvrsn=2>, accessed 31 October 2018 .

${ }^{234}$ However, the exclusion from the programme of the Corruption Practices Investigation Bureau ('CPIB') was criticised: 'Lawyers want CPIB included in video-recording pilot programme', The Business Times, 20 August 2015.

${ }^{235}$ 'Video recordings will help court assess statements', The Straits Times, 25 July 2017.

${ }^{236}$ Ministry of Law, 'Public Consultation on Proposed Amendments to the Criminal Procedure Code and Evidence Act' (24 July 2017), available online at: <https://www.mlaw.gov.sg/content/ minlaw/en/news/public-consultations/public-consultation-on-proposed-amendments-to-thecriminal-proce.html>, accessed 31 October 2018.

${ }^{237}$ The lack of publicly accessible government information and data is a problem that has been raised by Singapore academics in various disciplines including economics and sociology. See 'Academics call for more detailed, regular data sharing', The Straits Times, 25 October 2011.
} 


\subsection{Statistics on Police Dismissals, Internal Investigations and Actions Against Officers}

In a parliamentary speech delivered on 25 August 1994, the Parliamentary Secretary to the Minister for Home Affairs assured Parliament that allegations of Police abuse are not common. He revealed the following ${ }^{238}$ :

[In 1993], the [Internal Investigation Section, now called the Internal Affairs Office] investigated 94 complaints of Police abuse on suspects. This represents only $0.5 \%$ of the $18,000-19,000$ suspects arrested each year. Of these, only 14 cases were substantiated. The 16 errant officers involved have all been dealt with departmentally or even prosecuted in court. This figure represents less than $0.2 \%$ of our Police Force which totals over 10,600 officers.

A member of Parliament sought clarifications on two points ${ }^{239}$ : first, 'of the 14 cases that were substantiated, what kind of action was taken against the Police officers involved' and '[s]econdly, whether any confessions that were extracted in those circumstances were used in prosecutions against the offenders?' The Parliamentary Secretary did not answer the second question. In his answer to the first question, he revealed that '[o]ut of the 14 cases that were substantiated, one was prosecuted and charged in court. He was sentenced to one month imprisonment. The rest were departmentally dealt with. ${ }^{240}$

The same minister reported in 1998 that the number of complaints against police abuse of suspects had dropped to 56 in 1994 which was $0.2 \%$ of the total number of suspects arrested in 1997. Only 10 cases involving 14 officers were found to be substantiated following internal investigation and they were 'dealt with departmentally or prosecuted in court'. This was said to represent less than $0.12 \%$ of the total number of officers in the police force. ${ }^{241}$

More recently, it is reported in a newspaper that in the first 10 months of 2011, 16 police officers were sacked. It is further stated that '[b]etween 2007 and [2010], 80 police officers were dismissed. ${ }^{242}$

\footnotetext{
${ }^{238}$ 'Parliamentary Debates Singapore: Official Report', vol. 63 (25 August 1994) at col. 380 (Associate Professor Ho Peng Kee).

${ }^{239}$ 'Parliamentary Debates Singapore: Official Report', vol. 63 (25 August 1994) at cols. 383-384 (Associate Professor Walter Woon).

${ }^{240}$ ‘Parliamentary Debates Singapore: Official Report', vol. 63 (25 August 1994) at cols. 383-384 (Associate Professor Ho Peng Kee).

${ }^{241}$ 'Parliamentary Debates Singapore: Official Report', vol. 69 (1 June 1998) at cols. 97-98 (Minister of State for Home Affairs, Assoc Prof Ho Peng Kee).

${ }^{242}$ 'New unit set up to police errant cop', The Straits Times, 21 October 2011. The figures of dismissal were derived from a count of dismissal notices posted in the Government Gazette.
} 


\subsection{Exclusion of Statements}

It is uncommon for statements recorded by the police to be excluded. ${ }^{243}$ However, full data is not easily available. In 1995, the Parliamentary Secretary to the Minister for Home Affairs reported in Parliament that from 1993 to April 1995, statements were ruled inadmissible in four out of 166 cases tried in the High Court. No data was available for cases decided in the Subordinate Court. ${ }^{244}$ In 1998, the Minister of State for Home Affairs made the point in Parliament that the number of cases where a statement is challenged and excluded by the court is small. According to the Minister, that 'the police takes its work seriously; police knows that its work will be scrutinised by the courts'.

\subsection{Conviction and Acquittal Rates}

Anecdotally, the acquittal rate is low. There are no easily available statistics. It is reported that in 2011, ' 156 people were hauled to court as a result of [investigations by the Corrupt Practices Investigation Bureau ('CPIB')]. And in the last seven years, the conviction rate in such cases has hovered between 92 and $96 \%,{ }^{245} \mathrm{~A}$ press release by the CPIB on 2 April 2015 showed that the 'conviction rates (excluding withdrawal) for cases charged by the CPIB for corruption offences and other related offences remained high for the past 3 years, well above 95\% mark. ${ }^{246}$ It is unclear what inference is to be drawn from a high conviction rate. As one commentator observed, while one could argue that it reflects judicial reluctance to 'rule against the executive', it is equally 'consistent with a prosecutorial job so well done that only the obviously guilty are brought to court-even the most fair and independent minded judge would have little choice but to convict., ${ }^{247}$

\footnotetext{
${ }^{243}$ See PP v. Knight Glenn Jeyasingam [1999] 1 SLR(R) 1165 at [17]: "[t]aking the example of confessions, the Prosecution submitted that such statements... are rarely excluded in Singapore courts unless the voluntariness of the statement had been disproved.".

244،Parliamentary Debates Singapore: Official Report', vol. 64 (25 May 1995) at cols. 1109-1110. ${ }^{245}$ 'CPIB to mark 60 years of graft-busting', The Straits Times, 23 August 2012.

${ }^{246}$ Press Release by CPIB (2 April 2015) at [15]. Document available online at <https://www.cpib. gov.sg/sites/default/files/publication-documents/CPIB\%20Corruption\%20Statistics_0.pdf $>$, accessed 31 October 2018.

${ }^{247}$ Hor, 2002 at 507.
} 


\section{Conclusion}

Official discourse on the criminal process in Singapore tends to draw on crime control ideology. ${ }^{248}$ It is used for two main purposes. The first is to justify erosion or weak enforcement of rights, such as the right of silence and the right to counsel. The crime control ideology takes the suppression of crime as the dominant aim and is premised on an assumption about the impact of rights on crime control. To be strong on the suspect's rights, so the argument goes, is to be soft on crime, and, conversely, those rights needs to be weakened in order to be effective in crime control. The second is to justify judicial restraint from excessive interference with the work of the police. Judges should be mindful of the practical realities of criminal investigation when applying exclusionary rules. ${ }^{249}$

Rights of the accused are respected but they tend to be more narrowly construed or more weakly protected than in jurisdictions that are generally viewed as progressive. The approach taken in Singapore has been defended by pointing out how it has resulted in a low crime rate and by asserting the nation's right to set its own priorities and choose its own legal path. From time to time, concerns are aired about the criminal justice system and in connection with specific cases. These concerns have been raised in different fora-in Parliament, the press, online blogs, public speeches and professional and academic writings. Although there are reported instances of miscarriage of justice, none has generated sufficient controversy to be the catalyst for major reforms. Instead, change, when it comes about, tends come about slowly and incrementally. Singapore is concerned about its human rights image before the international community; how this will translate into legal reform in criminal justice is uncertain. International law thus far has had negligible impact in this area. There have been some welcome initiatives; especially welcome is the proposal to implement video-taping of police interviews. Certain changes have also alleviated previous perceptions of unfairness, such as the introduction of a new regime of pre-trial criminal disclosure. But there is still much that critics find to be unsatisfactory; particularly troubling is the difficulty the suspect faces in getting access to a lawyer at the police station.

\footnotetext{
${ }^{248} \mathrm{See}$, eg, Chan, 1996 at 438 ("If anything has been made clear in Singapore, it is that crime control has always been and is a high priority on the Government's action agenda"); Hor, 2001 at 28 ("official justifications of Singapore's criminal justice system appeal to Packer's 'crime control' model").

${ }^{249}$ See, eg, Fung Yuk Shing v. PP [1993] 2 SLR(R) 771 at [19]; Seow Choon Meng v. PP [1994] 2 SLR(R) 338 at [33]; PP v. Sng Siew Ngoh [1995] 3 SLR(R) 755 at [26]. Cf Law Society of Singapore v. Tan Guat Neo Phyllis [2008] 2 SLR(R) 239 at [143]: 'In Singapore, the Constitution establishes a form of parliamentary government (based on the Westminster model) based on the separation of the legislative, executive and judicial powers. Each arm of the government operates independently of the other and each should not interfere with the functions of the other.'
} 


\section{Addendum}

A number of developments have occurred after the completion of writing of this chapter. The Criminal Justice Reform Act 2018 was passed on 19 March 2018 and assented to by the President on 11 April 2018. A number of provisions in this Act were brought into force in September and October 2018. Among other changes, a new regime of audiovisual recording of statements taken by law enforcement officers have been introduced. For the moment, this is a requirement only for rape cases. There is intention to extend this gradually to other types of offences. Another change is the removal of the committal hearing for cases to be tried in the High Court.

\section{References}

\section{Books}

Chan, Sek Keong, 'From Justice Model to Crime Control Model', address before the International Conference on Criminal Justice Under Stress: Transnational Perspectives, New Delhi, India (24 Nov 2006). [Chan, 2006]

Choo, Andrew L-T, The Privilege against Self-incrimination and Criminal Justice, Oxford 2013. [Choo, 2013]

Packer, Herbert, The Limits of the Criminal Sanction, Stanford 1968. [Packer, 1968]

Philips, Cyril (Chairman), The Royal Commission on Criminal Procedure, Cmnd 8092, 1981. [Philips, 1981]

Pinsler, Jeffrey, Evidence and the Litigation Process $6^{\text {th }}$ edition, Singapore 2017. [Pinsler, 2017]

Tan, Yock Lin, Criminal Procedure, Singapore 2007. [Tan, 2007]

Thio Li-ann, A Treatise on Singapore Constitutional Law, Singapore 2012. [Thio, 2012]

\section{Journal articles}

Chan, Sek Keong, 'The Criminal Process - The Singapore Model', (1996) 17 Singapore Law Review, 433-503. [Chan, 1996]

Chin, Tet Yung, 'Criminal Procedure Code 2010: Confessions and Statements by Accused Persons Revisited', (2012) 24 Singapore Academy of Law Journal, 60-91. [Chin, 2012]

Chng, Melanie, 'Modernising the Criminal Justice Framework: The Criminal Procedure Code 2010', (2011) 23 Singapore Academy of Law Journal, 23-57. [Chng, 2011]

Chong, Steven, 'The Ethics of Criminal Practice', Singapore Law Gazette, April 2015, 12-22, available online at <http://v1.lawgazette.com.sg/2015-04/>, accessed 31 October 2018. [Chong, 2015]

Ho Hock Lai, 'On the Obtaining and Admissibility of Incriminating Statements', [2016] Singapore Journal of Legal Studies, 249-276. [Ho, 2016]

Ho Hock Lai, 'The Privilege against Self-incrimination and Right of Access to a Lawyer-A Comparative Assessment', (2013) 25 Singapore Academy of Law Journal, 826-846. [Ho, 2013] 
Ho, Hock Lai, “"National Values on Law and Order" and the Discretion to Exclude Wrongfully Obtained Evidence', [2012] Journal of Commonwealth Criminal Law, 232-256. [Ho, 2012]

Hor, Michael 'Singapore's Innovations to Due Process', (2001) 12 Criminal Law Forum, 25-40. [Hor, 2001]

Hor, Michael, 'The Future of Singapore's Criminal Process', (2013) 25 Singapore Academy of Law Journal, 847-873. [Hor, 2013]

Hor, Michael, 'The Independence of the Criminal Justice System in Singapore', (2002) 2 Singapore Journal of Legal Studies, 497-513. [Hor, 2002]

Hwang, Michael, 'A Protocol for Police Interviews of Witnesses and Suspects?', Singapore Law Gazette, June 2010, 1-4, available online at <http://v1.lawgazette.com.sg/2010-06/>, accessed 31 October 2018. [Hwang, 2010].

Lok, Vi Ming SC, 'When the Incredible Lawyer isn't an Appropriate Adult', Singapore Law Gazette, March 2013, 1-4, available online at: <http://v1.lawgazette.com.sg/2013-03/>, accessed 31 October 2018. [Lok, 2013]

Mohan, Chandra, 'Police Interrogation and the Right of Silence in the Republic of Singapore' (1986) 2 Malayan Law Journal, xxviii-xxxix. [Mohan, 1986]

See, Kee Oon, 'Criminal Case Resolution', [2013] Asian Journal on Mediation, 76-81. [See, 2013]

Soh, Kessler, "Criminal Case Resolution" in the Subordinate Courts of Singapore', [2011] Journal of Commonwealth Criminal Law, 209-225. [Soh, 2011]

Tan, Alan Khee-Jin, 'Adverse Inferences and the Right to Silence: Re-examining the Singapore Experience', [1997] Criminal Law Review, 471-481. [Tan, 1997]

Thio, Shen Yi, 'Vulnerable Suspects and Access to Counsel', Law Gazette, February 2016, 1-4, available online at: <http://v1.lawgazette.com.sg/2016-02/>, accessed 31 October 2018. [Thio, 2016]

Thio, Sheng Yi, President's Message, 'Enhanced CLAS Official Launch', Singapore Law Gazette, June 2015, 1-4, available online at <http://v1.lawgazette.com.sg/2015-06/>, accessed 31 October 2018. [Thio, 2015]

Wong, Denise Huiwen, 'Discovering the Right to Criminal Disclosure', (2013) 25 Singapore Academy of Law Journal, 548-579. [Wong, 2013]

Yeo, Stanley Meng Heong, 'Diminishing the Right to Silence: The Singapore Experience', [1983] Criminal Law Review, 88-101. [Yeo, 1983]

\section{Contributions to Edited Volumes and Annotated Law}

Singh, Sant, 'Treatment of Out-of-Court Statements in the Judicial Process', in: Teo Keang Sood (ed.), Singapore Academy of Law Conference 2006 - Developments in Singapore law between 2001 and 2005, Singapore 2006, 481-498. [Singh, 2006]

Hock Lai Ho is the Amaladass Professor of Criminal Justice at the NUS. He holds an LL.B. from NUS, a BCL from Oxford University and a Ph.D. from Cambridge University. He has published internationally in the fields of evidence, proof and aspects of the administration of criminal justice. His research ranges from doctrinal analysis of Singapore law to theoretical and comparative reflections on broader issues of the criminal trial. 
Open Access This chapter is licensed under the terms of the Creative Commons Attribution 4.0 International License (http://creativecommons.org/licenses/by/4.0/), which permits use, sharing, adaptation, distribution and reproduction in any medium or format, as long as you give appropriate credit to the original author(s) and the source, provide a link to the Creative Commons license and indicate if changes were made.

The images or other third party material in this chapter are included in the chapter's Creative Commons license, unless indicated otherwise in a credit line to the material. If material is not included in the chapter's Creative Commons license and your intended use is not permitted by statutory regulation or exceeds the permitted use, you will need to obtain permission directly from the copyright holder.

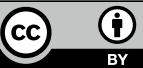

